\title{
BREAKING THE PRESUMPTION THAT APPLICANTS OF STATELESSNESS DETERMINATION PROCEDURES ARE FOREIGN
}

\author{
PAOLA PELLETIER QuiÑONES*
}

This article considers the situation of those who apply for a determination of their status as a stateless person but could, nonetheless, be nationals of the state in which they apply. Cases of in situ statelessness provide the greatest opportunity for the identification of these situations. After having identified 23 formal Statelessness Determination Procedures ('SDP') adopted as of 2020 from 23 countries, it is conclusive that these norms presume the applicant is foreign. However, eight countries have been identified that have safeguards in their SDP norms recognising the possibility that there could be identified applicants who may be nationals and containing procedures to follow in cases of doubt. These safeguards are adopted by four countries in the Americas (Costa Rica, Panama, Paraguay and Argentina) and four countries in Europe (Georgia, Moldova, Ukraine and Turkey). These constitute good practices that should be taken into consideration by further SDP norms adopted in the future, modifications of current SDP norms and statistics. This issue constitutes a 'red flag' for raising awareness of discriminatory state policies that assume stateless applicants are foreign and should receive second-class citizenship (naturalisation), rather than refer the case to the corresponding national civil registry authorities and facilitate access to nationality. The issues raised in this article have not previously been analysed in doctrine or by the United Nations High Commissioner for Refugees.

\section{TABLE OF CONTENTS}

I Introduction.

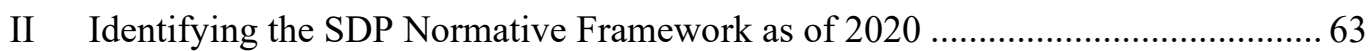

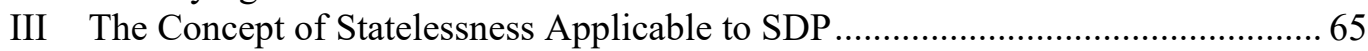

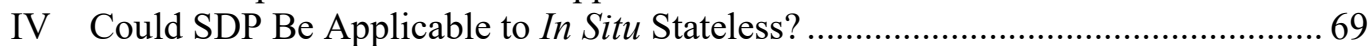

V Stateless People Presumed Foreign through SDP Norms...................................... 74

VI What If the Applicant Could Be a National of the Country in Which They Have Applied for a Determination of Their Stateless Status?......................................... 76

A Costa Rica: Executive Decree No 39620 of 2016 'Regulations for the Declaration of the Status of Stateless Persons' ('Decree No 39620') ....... 77

B Paraguay: Law No 6.149 'Protection and Assistance to Enable Naturalisation for Stateless Persons' ('Law No 6.149') ............................ 78

C Panama: Executive Decree No 10 of 16 January 2019 ('Executive Decree No 10').

D Argentina: Law No 27.512 'Recognition and Protection of Statelessness Persons' ('Law No 27.512')

* Master of Laws in International Legal Studies as Fulbright Fellow from American University, Washington College of Law, Washington, DC. Lawyer from Pontificia Universidad Catòlica Madre y Maestra ('PUCMM') (Summa Cum Laude), ex-litigation attorney, Human Rights activist, Law Professor at PUCMM for over 10 years in Dominican Republic of International Private Law and Fundamental Rights. Eight years with experience on Statelessness issues. Worked on protection in United Nations High Commissioner for Refugees ('UNHCR') Dominican Republic and international consultant on statelessness for UNHCR Regional Bureau of West and Central Africa. Ex-intern of the Inter-American Court of Human Rights in Costa Rica, to which I have presented amicus briefs on statelessness. Member of Reconocido Movement (Stateless) and the Feminist Movement in the Dominican Republic. This article is dedicated to Juan Ignacio Mondelli and Hervé Kuate; from my perspective, for their great contributions on Statelessness Determination Procedures ('SDP') in the Americas and Africa, respectively, and my gratitude. 
E Moldova: Law No 200 of 16 July 2010 on the Regime of Foreigners in the Republic of Moldova ('Law No 200')....

F Georgia: Ordinance No 523 'Approval of the Procedures for Determining the Status of a Stateless Person in Georgia' ('Ordinance No 523') ..........81

G Turkey: Implementing Regulation on Foreigners and International Protection ('Regulation on Foreigners and International Protection')..... 82

$\mathrm{H}$ Ukraine: Law of Ukraine on Amending Certain Legislative Acts of Ukraine Regarding Recognition as a Stateless Person ('Ukraine Statelessness Amendment Law').....

VII Commentary on The Safeguards against the Presumption That SDP Applicants Are

Foreign..... 83

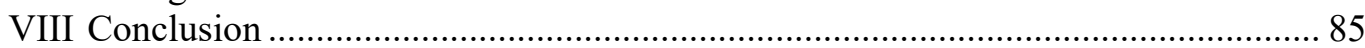

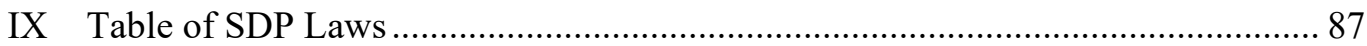

\begin{tabular}{|c|c|}
\hline \\
\hline \\
\hline \\
\hline rope & \\
\hline
\end{tabular}

\section{INTRODUCTION}

Neither the 1954 Convention Relating to the Status of Statelessness Persons ('1954 Convention') nor the 1961 Convention on the Reduction of Statelessness expressly regulate how states could adopt statelessness determination procedures ('SDP') as key tools for the identification and protection of stateless persons. ${ }^{1}$ Thus, states are left with discretion as to the design and operation of SDPs. ${ }^{2}$

For these reasons, the United Nations High Commissioner for Refugees ('UNHCR') and international experts have recommended that states enact SDPs for the identification and protection of stateless persons based on interpretations of the 1954 Convention. ${ }^{3}$ In 2014, UNHCR launched the '\#IBelong Campaign to End Statelessness by 2024 ', ${ }^{4}$ which provided a framework of 10 actions to end statelessness over a decade. The action concerning the adoption of SDPs for this

1 Good Practices Paper - Action 6: Establishing Statelessness Determination Procedures to Protect Stateless Persons (Good Practices Paper, UNHCR, July 2020) 4 ('Good Practices Paper 2020') 4.

Establishing a procedure or mechanism to identify stateless persons is thus an implicit obligation of the 1954 Convention. The 1954 Convention establishes the international legal definition of a 'stateless person' but is silent on how States are to determine whether an individual is stateless. Establishing an SDP is the most efficient means for States Parties to the 1954 Convention to identify the beneficiaries of that Convention.

See also Convention Relating to the Status of Stateless Persons, opened for signature 28 July 1951, 189 UNTS 150 (entered into force 22 April 1954) ('1954 Convention'); Convention on the Reduction of Statelessness, opened for signature 30 August 1961, 989 UNTS 185 (entered into force 13 December 1975).

2 Handbook on Protection of Stateless Persons under the 1954 Convention Relating to the Status of Stateless Persons (UNHCR 2014) 67 [64] ('Handbook on Protection of Stateless Persons').

3 Conclusion on Identification, Prevention and Reduction of Statelessness and Protection of Stateless Persons (Report No 106 (LVII), UNHCR 2006) ('UNHCR Conclusion'); Good Practices Paper - Action 6: Establishing Statelessness Determination Procedures to Protect Stateless Persons (Good Practices Paper, UNHCR 11 July 2016) 2 ('Good Practices Paper 2016'); Good Practices Paper 2020 (n 1).

4 See 'Global Action Plan to End Statelessness: 2014-2024', UNHCR (Web Page) $<$ https://www.unhcr.org/ibelong/global-action-plan-2014-2024/> ('\#IBelong Campaign'). 
campaign is Action 6: to 'grant protection status to stateless migrants and facilitate their naturalization' 5

In this regard, regional action plans to end statelessness that consider SDPs have been adopted. The Americas region was first, adopting the Brazil Declaration and Plan of Action: A Framework for Cooperation and Regional Solidarity to Strengthen the International Protection of Refugees, Displaced and Stateless Persons in Latin America and the Caribbean. 6 Subsequently, in West Africa, the Banjul Plan of Action of the Economic Community of West African States (ECOWAS) on the Eradication of Statelessness (2017-2024) was adopted. ${ }^{7}$

The Inter-American Commission of Human Rights has also recommended that states pass legislation providing SDPs for the identification and protection of stateless persons. ${ }^{8}$ However, the recognition of SDPs as a key tool for the identification and protection of stateless populations has not yet been yet decided by international jurisprudence. The Inter-American Court of Human Rights, the European Court of Human Rights and the African Court on Human and Peoples' Rights have not yet decided a case recognising SDPs as an obligation derived from the 1954 Convention. Currently, there is no international jurisprudence ordering and recognising the obligation of states to adopt SDPs or modify an SDP norm according to international standards.

Despite an increasing awareness in recent years that stateless persons are distinct from refugees and migrants, and that statelessness issues shall be addressed distinctly from migrants and refugee issues, states continuously fail to adopt procedures for statelessness determination with autonomous character, separated or apart from refugee or asylum procedures and protection mechanisms.

There are countries, mostly in Europe, where statelessness status is recognised through ad hoc mechanisms. Consequently, the recognition of such status is diluted in norms, administrative practices and measures, or judicial practices within the scope of asylum, migration or citizenship procedures, and not formally recognised in specialised procedures for statelessness status determination. ${ }^{9}$ As Noémi Radnai explains, 'It is not simply "black or white" whether a state has an SDP established in its domestic law', it should be considered a formal SDP when the law expressly regulates a specific procedure for the determination of the status of stateless persons. ${ }^{10}$

5 ibid

6 Brazil Declaration and Plan of Action: A Framework for Cooperation and Regional Solidarity to Strengthen the International Protection of Refugees, Displaced and Stateless Persons in Latin America and the Caribbean (Declaration, Cartagena +30 3 December 2014).

7 Banjul Plan of Action of the Economic Community of West African States (ECOWAS) on the Eradication of Statelessness 2017-2024 (Action Plan, Economic Community of West African States 2017).

8 See Due Process in Procedures for the Determination of Refugee Status and Statelessness and the Granting of Complementary Protection (Report, OAS and Inter-American Commission on Human Rights, 2020) ('Procedures for Determination of Refugees and Statelessness'); 'IACHR Welcomes Actions to Protect the Right to a Nationality and to Prevent Statelessness in the Region', Organization of American States (Press Release, 2019) $<\mathrm{http}$ ://www.oas.org/en/iachr/media_center/PReleases/2019/042.asp>.

9 Ad hoc mechanisms for statelessness status recognition can be found in Czech Republic, Finland, Germany, Slovak Republic, Slovenia, Sweden, Norway, Croatia, Malta, Poland, Ireland and Belgium. See ENM Inform: Statelessness in the EU (Report, European Migration Network, 2016) 2, 5, 8, $13 \quad<$ https://www.emnluxembourg.lu/wpcontent/uploads/2016/11/EMN-Inform-Statelesseness-in-the-EU.pdf $>$.

10 Noémi Radnai, Statelessness Determination in Europe: Towards the Implementation of Regionally Harmonised National SDPs (Working Paper No 2017/8, $5^{\text {th }}$ ed, Institute of Statelessness and Inclusion 2017) $6<$ https://files.institutesi.org/WP2017_08.pdf >. 
As of 2020, SDPs have been enacted by 23 states, either through norms or legislation. ${ }^{11}$ These SDP norms establish specific procedures for statelessness status determination, addressing the protection of stateless populations independent of migration and asylum procedures. The recognition of SDPs with autonomous character, establishing specific regulations in this subject matter, constitutes a state's positive political will for the identification, recognition and protection of stateless persons.

As a starting point, SDP norms consider stateless persons as foreigners. Successful SDP applicants are recognised by the state as stateless, have the right to documentation (ID and residence) and access to naturalisation. ${ }^{12}$ Naturalisation is a durable solution for statelessness and one of the keys for integrating stateless persons into society. Similarly, naturalisation is a durable solution for migrants and refugees, ${ }^{13}$ who also are considered foreigners by states.

Nevertheless, there is a concern that shall be addressed throughout this article: those who have the right to nationality could be considered 'foreign' by their own state. Stateless persons can be born in the territory of the state or have strong links given an extensive period of living in the state. What if, then, an applicant could be a national of the country in which they have applied for a determination of statelessness status? An application that may be made whether the applicant is aware of their nationality or citizenship rights in the country to which they have applied or not. Could a formally adopted SDP be used by states to perpetuate a policy of exclusion or denationalisation? These questions have not been addressed nor discussed by the doctrine or UNHCR within SDP contexts.

For these reasons, this article raises an alert or 'red flag' when applicants in SDPs could be nationals of the state in which they have applied for recognition of their status as stateless; meaning, therefore, that an SDP is not the procedure that corresponds to their case. It is important to identify such cases, regulate due process and, moreover, underline the importance of state will towards recognising their right to citizenship.

Of the 23 states that have enacted SDPs as of 2020, eight countries have included safeguards in their SDP norms for identification, investigation and referral mechanisms where the applicant could be identified as a national of the state in which they have applied to be recognised as stateless. The applicant would not be eligible to be recognised as stateless, but would be recognised as a citizen of the state in which they have wrongly applied for a status of statelessness. These safeguards in the SDP normative framework constitute good practice and guidance

11 The author of this article read statelessness determination procedure ('SDP') norms in their original languages: Spanish, English, French, Portuguese and Italian. SDP norms from Turkey, Montenegro, Ukraine, Moldova, Kosovo, Georgia, Latvia, Bulgaria and Hungary were read and analysed from unofficial translations into English. For the purposes of this article, the words 'citizenship' and 'nationality' have the same meaning. Also, the term 'norm' or 'law' will be understood in a broad manner, either as an SDP law enacted by the congress or parliament of a country; or an SDP norm issued through a decree, resolution or the application of rules issued by a state's executive branch or its corresponding ministries or agencies.

121954 Convention (n 1) art 32. See also UNHCR Conclusion (n 3); Good Practices Paper 2016 (n 3) 1, 8; Good Practices Paper 2020 (n 1) 20-22; Handbook on Protection of Stateless Persons (n 2) 25 [58].

13 Executive Committee of the High Commissioner's Programme, Solutions: Ending Displacement and Statelessness, 72 ${ }^{\text {nd }}$ Meeting, EC/69/SC/CRP.10/Rev.1 (7 June 2018) [3], [13]; Procedures for Determination of Refugees and Statelessness (n 8) 106 [289]; Eva Mrekajova, 'Naturalization of Statelessness Persons: Solutions of Statelessness?' (LLM Thesis, International and European Public Law, Tilburg University 2012) 5, 52, 54. 
that must be considered by current and future SDP norms and their corresponding rules of application.

In this regard, with the aim of sharing reflections and concerns, the present article has been divided into seven parts: Part I, this introduction; Part II identifies the SDP norms adopted by states as of 2020; Part III addresses the concept of statelessness, as recognised in the SDP norms adopted by states; Part IV presents the question of whether SDPs are applicable or not to in situ statelessness; Part V discusses how the stateless are presumed 'foreign' in SDP norms; Part VI describes eight SDP norms that establish a route of action where an applicant could be identified as a national of the country in which they have applied for a determination of their status; and Part VII consists of commentaries on these safeguards as good practices against the presumption that an SDP applicant is foreign.

\section{IDENTIFYING THE SDP NORMATIVE FRAMEWORK AS OF 2020}

Most of the existing formal SDP mechanisms have been adopted in Europe and the Americas. As of 2020, in the Americas, eight countries had adopted an SDP: Mexico was the first in 2012, then Costa Rica (2016), Brazil (2017), Ecuador (2017), Paraguay (2018), Uruguay (2018) and Panama and Argentina were the last in 2019, respectively. ${ }^{14}$ In Europe, there are 13 countries: France was the first in 1952,15 then Italy in 1994, Spain (2001), Latvia (2004), Hungary (2007), Moldova (2010), UK (2013), Georgia (2014), Kosovo (2015), Turkey (2016), ${ }^{16}$ Bulgaria (2017), Montenegro (2018), and the last was Ukraine in 2020. In Asia, only one country, the Philippines (2012), has issued an SDP, while the first SDP in Africa was recently established by Côte d'Ivoire in 2020.17

14 Neither the Inter-American Commission of Human Rights nor UNHCR recognise Colombia as having a formal SDP mechanism (see Good Practices Paper 2020 (n 1)). Circular No 168 (2017) (Colombia) ('Circular No 168') issued by the Ministry of Foreign Affairs of Colombia was cited by the Constitutional Court of Colombia concerning the risk of statelessness for Venezuelan children born in Colombia from parents of irregular migratory status; the Court made reference to Circular No 168, considering the impossibility in material and political reasons for consulting the Venezuelan Consulate in Colombia concerning the nationality of children born in this country from Venezuelan parents. See Sentencia T-006/20: Derecho a la Nacionalidad de los Niños y Niñas Hijos de Extranjeros que se Encuentran en Riesgo de Apatridia en Colombia [Sentence T-006/20: Right to Nationality of Children of Foreigners who are at Risk of Statelessness in Colombia] (2020) (Constitutional Court of Colombia) $<$ https://www.corteconstitucional.gov.co/Relatoria/2020/T-006-20.htm> ('Sentence T$\left.006 / 20^{\prime}\right)$.

15 In 1952, France became the first country in the world to expressly adopt a formal law regulating an SDP distinct from their refugee statelessness determination procedure ('RSD'). 'French statelessness-specific protection mechanism (the oldest in the world) was created in 1953[sic], thus it actually pre-dates the 1954 Statelessness Convention': Gábor Gyulai, 'Statelessness in the EU Framework for International Protection' (2012) 14(1) European Journal of Migration and Law 279, 290. See also Law No 1952-893 of 1952 Concerning the Creation of a French Office for the Protection of Refugees and Stateless Persons (France).

16 For the purposes of this article, Turkey will be considered as geographically in Europe, since it is part of the European Council and is a candidate for the European Union. See 'Turkey// 47 States, One Europe', Council of Europe (Web Page, 2019) $<$ https://www.coe.int/en/web/portal/turkey\#: :text=Turkey\%20became\%20the\%2013th\%20 member,Europe\%20on\%2013\%20April\%201950>; 'Turkey: Membership Status', European Commission (Web Page) <https://ec.europa.eu/neighbourhoodenlargement/countries/detailed-country-information/turkey_en>.

17 For a full list of these laws and their surrounding legal instruments, see Part IX: Table of SDP Laws. 
Additionally, the 23 SDPs identified for this article coincide in that the 23 countries they correspond to are parties to the 1954 Convention. They are also recent: since 2014, seven out of eight countries in the Americas adopted SDP norms, and seven of 13 countries (54\%) in Europe. From a total of 23 countries with formal mechanisms for SDPs, 14 (61\%) established SDP legislation after 2014, while only five countries (European countries) implemented SDP norms before 2010: France, Italy, Spain, Latvia and Hungary. Clearly, the legislation in force concerning SDPs is a relatively new development and likely related to the impact of the UNHCR \#IBelong Campaign launched in 2014 to end statelessness. ${ }^{18}$

These SDP norms are laws enacted by a congress or parliament, or by resolutions or rules issued by an executive branch. There are countries that have recognised stateless persons through migration or citizenship laws enacted by congress or parliament and, later, their SDP was adopted by resolution or the application of rules. These resolutions or rules can be issued by the executive branch (ie, ministries of foreign affairs, ministries of justice or immigration offices) or by royal decree, as in Spain. This is the case in the Americas (Mexico, Costa Rica, Ecuador and Brazil) and in Europe (Italy, Hungary, Spain, Kosovo, Bulgaria, Montenegro and Turkey). ${ }^{19}$

On the other hand, there are countries whose organic laws on citizenship or immigration have not previously or expressly regulated the topic of statelessness. Nevertheless, such countries have adopted SDPs by decree or resolution issued by executive branches of government. ${ }^{20}$ For example, the SDP in the Philippines was established by the Department of Justice; in Côte d'Ivoire as a joint resolution from the Ministry of Foreign Affairs and Ministry of Justice; and, in Panama, the SDP was adopted by decree from the executive branch.

There are also countries that have adopted SDPs as special laws enacted by a congress or parliament, providing the SDP with a stronger guarantee - the law comes from the political power of the 'people' represented in these constitutional organs. Paraguay, Uruguay and Argentina have enacted specialised laws on SDPs, while statelessness is not recognised nor identified in their organic migration or citizenship laws. In contrast, Georgia, Latvia and Ukraine, which are states that have emerged in the last 30 years, recognise statelessness in their immigration or organic laws and have adopted specific 'statelessness laws' without an SDP. These European countries later modified their migration or citizenship laws to include SDPs through laws enacted by parliament or congress, or by an act of their executive branch. In Moldova, citizenship and foreigner laws were directly amended to include an SDP through laws passed by their parliament. The same occurred in France and the United Kingdom, whose immigration codes regulated

18 '\#IBelong Campaign' (n 4). For this analysis see Part IX: Table of SDP Laws.

19 See Part IX: Table of SDP Laws.

20 For example, Colombia and Luxembourg, through their respective Ministries of Foreign Affairs, issued a 'circular' and a 'note', respectively, adopting some mechanism for statelessness status recognition. Although these administrative measures are not considered a formal mechanism for statelessness status recognition, these administrative measures issued by an agency from the executive branch describe a basic procedure. See Ministry of Foreign Affairs of Colombia: Circular No 168 (n 14), cited in Sentence T-006/20 (n 14). See also 'Application for the Status as a Stateless Person', Le Gouvernment du Grand-Dushe de Luxembourg (Web Page, 2016) < https://guichet.public.lu/en/citoyens/immigration/casspecifiques/apatride/demande-statut-apatride.html $>$. 
refugee statelessness determination ('RSD') procedures but were amended by law to include SDPs.

Finally, all 23 SDP norms state that their application and procedure are conducted by the same authority that conducts RSD. Despite this, there is not a general move to unify SDP and RSD procedures into a single law. Instead, the tendency leans towards countries enacting specialised norms on SDPs to create and develop expertise on statelessness, ${ }^{21}$ for advocacy and donation purposes. These tendencies leave statelessness with its own line of actions and indicators, distinct from migration or refugee issues. As a result, statelessness is becoming visible through SDPs, separated from the shadows of migration and asylum concepts, norms and procedures.

\section{The CONCEPT OF STATELESSNESS APPlicABLE TO SDP}

The official conceptualisation of statelessness agreed by states can be found in art 1(1) of the 1954 Convention: 'a person not recognised as a national by any state under the operation of its law'. This is considered as de jure statelessness. ${ }^{22}$ However, the concept of statelessness has arguably been extended; statelessness could be understood as no longer just the result of a conflict of laws, gaps or ambiguities in the normative framework.

The reality of statelessness could be said to go beyond the 'operation of law'; that is to say, the reality of statelessness goes beyond conflicting laws, gaps or ambiguities in the laws of the states in question. ${ }^{23}$ The following situations are some examples of challenging issues in terms of identifying who is stateless.

\section{A Person Holds National ID but Cannot Enjoy Full Rights Attached to Nationality}

This relates to persons who have the right to citizenship by law but, given different reasons (material or political), cannot effectively enjoy all or part of the rights attached to nationality. This includes the right to vote, birth registry of

21 Expert Meeting: Statelessness Determination Procedures and the Status of Stateless Persons (Summary Conclusions, UNHCR, 6-7 December 2010) ('Geneva Conclusions') 3. See also Good Practices Paper 2020 (n 1).

22 Expert Meeting: The Concept of Stateless Persons under International Law (Summary Conclusions, UNHCR 27-28 May 2010) 1 ('Prato Conclusions'); Handbook on Protection of Stateless Persons (n 2) 5.

23 This article will not address discussions concerning de facto statelessness, which here is considered as imperfect or ineffective nationality. That is, a person could be entitled by law to a right of nationality or they could hold a national ID card but, despite this, cannot enjoy part or all the rights attached to the right of nationality. See David Weissbrodt and Clay Collins, 'The Human Rights of Stateless Persons' (2006) 28(1) Human Rights Quarterly 245, cited in Hugh Massey, Legal and Protection Policy Research Series: De Facto Statelessness (Report, No LPPR/2010/01 UNHCR, April 2010) 28. 'Since ... the interpretation of the term is subject to debate, ... the researchers decided, as far as possible, to avoid the use of the terms de jure and de facto stateless'. Laura van Waas, Nationality Matters: Statelessness under International Law (Intersentia 2008) 2; Prato Conclusions (n 22) 5; United Nations High Commissioner for Refugees, Guidelines on Statelessness No 1: The Definition of 'Stateless Person' in Article 1(1) of the 1954 Convention Relating to the Status of Stateless Persons, UN Doc HCR/HS/12/01 (20 February 2012) ('Guidelines No 1'). Published in 2014, the Handbook on Protection of Stateless Persons (n 2) 5 [7] recommended not to differentiate between de jure or de facto statelessness, as the 1954 Convention (n 1) does not categorise either. Meaning, therefore, any situation that could cause a person become statelessness or at risk of statelessness is subject to protection. 
descendants, the acquisition of property etc. ${ }^{24}$ This also applies when nationality is restored by an act of recognition by the state but, in practice, the person cannot effectively access to all or part of the rights attached to nationality. ${ }^{25}$ Persons in this category might be considered de facto stateless, however, if the state does not recognise them as a national they may also be de jure stateless.

Persons who have the right to a nationality of a state according to its constitution or citizenship laws, but are unable to enjoy the rights attached to nationality owing to administrative and procedural hurdles, incorrect interpretation of norms, lack of information, costs, inexistence of diplomatic missions or other material reasons may also, in fact, be stateless if these circumstances amount to a state not recognising them as a national.

24 For example, in Latvia, according to Law on the Status of Those Former USSR Citizens Who Are Not Citizens of Latvia or Any Other State (1995) 63 Latvijas Vēstnesis (Latvia) ('Law on Former USSR Citizens'):

there are two groups of concern to UNHCR: the 'non-citizens', and stateless persons determined in the Statelessness Determination Procedure. While the 'non-citizens' in Latvia are entitled to rights that generally beyond the minimum rights prescribed by the 1954 Convention, and as such they may be considered persons to whom the Convention does not apply in accordance with Article 1.2(ii). In comparison with the situation of citizens of Latvia, differences exist in access to employment, property purchases, political rights and pensions.

Latvia Fact Sheet (Fact Sheet, UNHCR 2021) 2 $<$ https://reporting.unhcr.org/sites/default/files/Biannual\%20fact $\% 20$ sheet $\% 202021 \% 2002 \% 20$ Latvia.pdf>. See also 'Latvia', Statelessness Index (Web Page, 2020) <https://index.statelessness.eu/country/latvia> ('Statelessness Index: Latvia').

'non-citizens' in Latvia clearly lack a nationality and therefore meet the definition of a stateless person under international law regardless of any separate legal consideration of whether they should be excluded from protection under the 1954 Convention.

25 For example, in 2014, the Dominican Republic issued Law No 169/2014 recognising Dominicans of Haitian descent registered in the civil registry; the beneficiaries still face challenges accessing to documentation and the rights attached to nationality, such as registering their offspring. See Ley No 169/2014 Establece un Régimen Especial Para Personas Nacidas en el Territorio Nacional Inscritas Irregularmente en el Registro Civil Dominicano y Sobre Naturalización [Law No 169/2014 Establishing a Special Regime for People Born in the Territory National Irregularly Registered in the Dominican Civil Registry and about Naturalization], 10765 GO (Dominican Republic). Therefore, it is important to keep monitoring countries that have recognised, confirmed or returned nationality, as in practice, beneficiaries could not effectively access ID nor the attached rights given administrative, material or political reasons and could be at risk of statelessness. For example, consider the current situation of the Makondes (2016) and Shona (2020) peoples. They were in situ stateless populations that were recently recognised as ethnic group nationals of Kenya. See Kenya (Submission, UNHCR 3 $<$ https://www.refworld.org/type,COUNTRYREP,,KEN,5e1732de2,0.html>. See also 'End of Statelessness for the Shona in Kenya: The Journey Towards Citizenship', Kenya Human Rights Commission (online, 12 January 2021) < https://www.khrc.or.ke/2015-03-04-10-3701/blog/733-end-of-stateleness-for-the-shona-in-kenya-the-journey-towardscitizenship.html>. 
When a constitution or law recognises a person's right to nationality but the interpretation and application of these norms by authorities (including the judiciary) denies citizenship or ID to certain groups with specific characteristics, as well as to their subsequent generations, they are likely to be de jure stateless. ${ }^{27}$ These acts result in the 'arbitrary deprivation of nationality', 28 rendering the person or group of persons stateless. ${ }^{29}$

\section{$4 \quad$ Silence Concerning Citizenship or Denial of Citizenship by Diplomatic Mission}

A person may hold an ID or passport, but a diplomatic mission denies its issuance or renewal. Moreover, diplomatic missions of the same state located in different countries may apply different criteria concerning laws on citizenship.

\section{Deported Nationals}

Persons who may or may not have an ID and are deported from their country of nationality or deported from a country with which they maintain strong links or

26 There are systematic patterns of historical discrimination and domination against certain groups who are marginalised and subject to stereotypes (indigenous populations, tribes, afro descendants, women, persons with disabilities, LGBTQ + , migrants, refugees and stateless persons to name a few), facing inequalities either de jure or de facto from the state and general society. Paola Pelletier, Discriminación Estructural en la evolución de la Jurisprudencia de la Corte Interamericana de Derechos Humanos [Structural Discrimination in the Jurisprudential evolution of the Inter-American Court of Human Rights] (2014) 60(1) Revista Instituto Interamericano de Derechos Humanos 206, 206-7.

27 If a person has their nationality 'confirmed' by the state, subsequent generations may be entitled to a right of nationality by jus sanguinis, however, they may face challenges if subsequent generations are not documented. 'It was noted that unresolved situations of de facto statelessness, in particular over two or more generations, may lead to de jure statelessness'. Prato Conclusions (n 22) 8.

28 See van Waas (n 23) 24, 25. See also Human Rights and Arbitrary Deprivation of Nationality: Report of the Secretary General, UN Doc A/HRC/25/28 (19 December 2013) ('Human Rights and Arbitrary Deprivation of Nationality'); United Nations High Commissioner for Refugees, Guidelines on Statelessness No 5: Loss and Deprivation of Nationality under Articles 5-9 of the 1961 Convention on the Reduction of Statelessness, UN Doc HCR/GS/20/05 (May 2020) ('Guidelines No 5').

29 For example, in situ stateless populations who also have been collectively deprived of citizenship are, Rohingyas in Myanmar; Kurds in Syria; Bidoons in Kuwait (Bidoun or Bidun), which means 'without' in Arabic; Muslim minorities in Assam (India); Dominicans of Haitian Descent in Dominican Republic. See José María Arraiza; Marina Arraiza Sharikova and Phu Zin Aye, 'Statelessness Motivated by Nativism, Racism and Xenophobia: A Comparison of Myanmar, the Dominican Republic and India' in The World's Stateless Deprivation of Nationality (Report, Institute of Statelessness and Inclusion 2020) 163, 16375; Case of Dominicans and Haitian People Expelled v Dominican Republic (Judgment) (Inter-American Court of Human Rights, Series C No 282, 28 August 2014) [232]-[233], [323] ('Dominicans and Haitians Expelled'); Stateless in Syria: Country Position Paper (2009) 8, 13-15<https://statelessjourneys.org/wp-content/uploads/StatelessJourneys-SyriaAugust-2019.pdf>; Syrian Citizenship Disappeared: How the 1962 Census Destroyed Stateless Kurds' Lives and Identities (Report, Syrians for Truth and Justice 2018) $<$ https://www.stj-sy.com/en/view/745>; Stateless in Kuwait (Country Position Paper, European Network on Statelessness and Institute of Statelessness and Inclusion 2019) 5-7 $<$ https://statelessjourneys.org/wp-content/uploads/StatelessJourneys-Kuwait-FINAL.pdf $>$. 
long-term residence may also be de jure stateless. These acts also constitute an arbitrary deprivation of nationality. ${ }^{30}$

Nomads, ${ }^{31}$ cultural stereotypes - such as gender issues, ${ }^{32}$ changes to state borders, ${ }^{33}$ trafficking, ${ }^{34}$ or the non-recognition of states by the international community (emerging or contested statehood) may all lead to de jure statelessness. $^{35}$

30 Anudo Ochieng Anudo v United Republic of Tanzania (African Court on Human and Peoples' Rights, App No 012/2015, 22 March 2018). Slivenko v Latvia (2003) X Eur Court HR 229 [96] ('Slivenko'); Dominicans and Haitians Expelled (n 29) [381]-[389].

31 For example, Nomadic Bedouins or Bidoons ('those without status') in the Middle East and West and North Africa. See Regional Expert Meeting on the Human Rights of Stateless Persons in the Middle East and North Africa (Report, UNHCR and OHCRH 18-19 February 2010) 24, 31. See also Heather Alexander, 'Nomads and the Struggle for a Legal Identity' (2020) 2(2) Statelessness \& Citizenship Review 338, 339. Also, the Roma population in Europe. See Roma Access to Personal Documentation in the Western Balkans (Report, European Union and UNDP 2018); Ending Childhood Statelessness in Europe (Advocacy Brief, UNICEF and UNHCR January 2019) 2,4 $<\mathrm{https}: / /$ www.unhcr.org/5c63e7864.pdf?query=Statelessness $>$; Birth Registration and the Prevention of Statelessness in Europe: Identifying Good Practices and Remaining Barriers (Thematic Briefing, Statelessness Index, May 2020) 9.

32 For example, women cannot pass nationality to their children because of an express prohibition in some laws. Similar deprivation can occur if the child is born out of wedlock or if the father is unknown, has passed away or is stateless. As a result, children and subsequent generations can be stateless. Such discriminatory laws based on gender are identified in Kuwait, Lebanon, Iran, Qatar, Somalia and Eswatini: Background Note on Gender Equality, Nationality Laws and Statelessness (Background Note, UNHCR 2019) 6. Another example is that in Syria, women and men could not get married if they profess different religions and, therefore, could not register the birth of their children: Legislative Decree No 59 of 1953 'Personal Status Law', art 48(2) (Syrian Arab Republic); Concluding Observations on the Fifth Periodic Report of the Syrian Arab Republic, UN Doc CRC/C/SYR/CO/5 (6 March 2019) [24](d).

33 For example, state succession, including South Sudan in 2011 and the 15 European countries that emerged from the former Soviet Union after 1991. Also, international judgment orders occasionally change the borders of states in international disputes over land or sea borders, such as in the International Court of Justice case, Frontier Dispute (Burkina Faso v Niger) [2013] ICJ Rep 44.

34 See Human Rights Committee, Views Adopted by the Committee under Article 5(4) if the Optional Protocol, Concerning Communication No 2918/2016, UN Doc CCPR/C/130/D/2918/2016 (28 December 2020) ('DZ v The Netherlands').

35 Several states and the United Nations do not recognise the statehood of Palestine or Western Sahara (the Saharawi living in the exile in Algeria). These statehood issues also have an impact on statelessness. For example, on the lack of diplomatic missions in different states (consulates), gaps in their nationality laws or a lack of clear data to identify the stateless population. Concerning the contested statehood of these countries, see Status of Palestine in the United Nations, UN Doc A/RES/67/19 (4 December 2012); Resolution 2548 (2020), UN Doc S/RES/2548 (30 October 2020):

Reaffirming its commitment to assist the parties to achieve a just, lasting, and mutually acceptable political solution, based on compromise, which will provide for the selfdetermination of the people of Western Sahara in the context of arrangements consistent with the principles and purposes of the Charter of the United Nations, and noting the role and responsibilities of the parties in this respect.

Reiterating its call upon Morocco, the Frente Polisario, Algeria and Mauritania to cooperate more fully with each other, including through building additional trust, and with the United Nations, as well as to strengthen their involvement in the political process and to achieve progress towards a political solution. 
The aforementioned realities and causes of statelessness may be difficult to fit within the strict interpretation of the concept of statelessness agreed by states in 1954. Given this, UNHCR has held special consultation meetings with international experts and has adopted different guidelines over the past 20 years on these matters. One of the key conclusions and recommendations is that the interpretation and application of 'law' in art 1(1) shall broadly be 'to encompass not just legislation, but also ministerial decrees, regulations, orders, judicial case law ... and, where appropriate, customary practice'. ${ }^{36}$ Consequently, the scope of art 1(1) includes state practices, administrative measures (written or not) and cultural stereotypes as causes of statelessness.

Finally, the recognition of statelessness, as it is conceptualised in art 1(1) of the 1954 Convention, has impacted states through its incorporation into national legislation. Thus, at the core of SDP lies the concept of statelessness as stated in art 1(1) of the 1954 Convention, as it is recognised in national legal systems and within the bounds of its corresponding extended interpretation.

\section{COUld SDP Be ApPlicABle to IN Situ StATELESS?}

Statelessness results from both migratory and non-migratory contexts. ${ }^{37}$ Stateless migrants and refugees in situations of displacement are considered ex situ stateless since they are out of their country of nationality. ${ }^{38}$ By comparison, in situ stateless populations were born or have lived for a long time within the territory or boundaries of their country of 'habitual residence' 39 (even since the time of that state's independence, succession or self-determination). Both profiles can have strong roots within the country (family, social, cultural and economic) and might

Concerning Palestinians and Saharawi's statelessness and refugee stateless, see The World's Stateless - Deprivation of Nationality (Report, Institute of Statelessness and Inclusion 2020) 10-11, 24, 53, 105, 127-32 (concerning Palestine) 24, 121-22 (concerning the Saharawi Arab Democratic Republic).

36 Guidelines No 1 (n 23) [5].

37 Statelessness Determination and the Protection of the Status of Statelessness Persons (Report, European Network on Statelessness 2013) $<$ https://www.refworld.org/pdfid/53162a2f4.pdf> ('Statelessness Determination').

38 'Stateless people in a migratory context are persons who are migrants or have a migratory background. They have no or no meaningful connections to the country they live in'. Caia Vlieks, Understanding Statelessness: What Are the Different Contexts of Statelessness in Europe, European Network on Statelessness (Blog Post, 14 September 2017) $<$ https://www.statelessness.eu/updates/blog/understanding-statelessness-what-are-differentcontexts-statelessness-europe> ('Understanding Statelessness Contexts in Europe').

39 United Nations High Commissioner for Refugees, Guidelines on Statelessness No 3: The Status of Stateless Persons at the National Level, UN Doc HCR/GS/12/03 (17 July 2012) 2, 5 ('Guidelines No 3').

The condition that a stateless person be 'habitually resident' or 'residing' indicates that the person resides in a Contracting State on an on-going and stable basis. 'Habitual residence' is to be understood as stable, factual residence. This covers those stateless persons who have been granted permanent residence, and also applies to individuals without a residence permit who are settled in a country, having been there for a number of years, who have an expectation of ongoing residence there. 
never have crossed international borders. ${ }^{40}$ Thus, in situ stateless persons "consider themselves to already be "in their own country". 41

A current major challenge is mapping and identifying stateless populations. This is a challenge for a number of different reasons, such as a lack of awareness, a lack of political will, the denial of the existence of stateless populations by states, a lack of reporting by governments or a failure to conduct official or non-official mapping (studies, census or surveys). ${ }^{42}$

As of 2019, 'ten countries that report the largest stateless populations accounted for over $87 \%$ of the overall number of stateless counted'. ${ }^{43}$ They are located in Europe, Asia, Africa and Middle East: Côte d'Ivoire, Bangladesh, Myanmar, Thailand, Latvia, Syria, Malaysia, Uzbekistan, Kuwait and Estonia. ${ }^{44}$ In the

40 Understanding Statelessness Contexts in Europe (n 38):

Stateless in situ are commonly in a non-migratory situation and remain stateless in their 'own country', often since birth. They are long-standing residents (or were residents at the time of state succession) with close personal and family ties to the country and a clear intention to stay. They also do not have such ties to other countries.

41 Geneva Conclusions (n 21) 2; the Human Rights Committee, interpreting International Covenant on Civil and Political Rights, opened for signature 16 December 1966, 999 UNTS 171 (entered into force 23 March 1976) art 12(4) ('ICCPR') stated:

[t]he scope of 'his own country' is broader than the concept 'country of his nationality'. It is not limited to nationality in a formal sense, that is, nationality acquired at birth or by conferral; it embraces, at the very least, an individual who, because of his or her special ties to or claims in relation to a given country, cannot be considered to be a mere alien.

CCPR General Comment No 27: Article 12 (Freedom of Movement), UN Doc CCPR/C/21/Rev.1/Add.9 (2 November 1999) [20] ('General Comment 27'). On interpreting what the concept 'his own country' means, the Human Rights Committee has further stated:

['his own country'] is not limited to nationality in a formal sense, that is, nationality acquired at birth or by conferral; it embraces, at the very least, an individual who, because of his or her special ties to or claims in relation to a given country, cannot be considered to be a mere alien. In this regard, it finds that there are factors other than nationality which may establish close and enduring connections between a person and a country, connections which may be stronger than those of nationality. The words 'his own country' invite consideration of such matters as long standing residence, close personal and family ties and intentions to remain, as well as to the absence of such ties elsewhere.

Communication No 1959/2010, UN Doc CCPR/C/102/D/1959/2010 (1 September 2011) [8.5]; Guidelines No 3 (n 39) 11 [45].

42 See Statelessness in Numbers: 2020 - An Overview and Analysis of Global Statistics (Report, Institute on Statelessness and Inclusion, August 2020) 3 $<$ https://files.institutesi.org/ISI_statistics_analysis_2020.pdf> ('Statelessness in Numbers: 2020'), which analysed statelessness population numbers from Global Trends: Forced Displacement in 2019 (Report, UNHCR, 2019) ('Global Trends 2019').

43 Statelessness in Numbers: 2020 (n 42 ) 3.

44 ibid 3, 8. 
Americas, the United States ${ }^{45}$ and Dominican Republic ${ }^{46}$ could be considered to have the largest stateless populations in this region despite the lack of official data.

Most stateless persons in these countries are in situ stateless except for those in Bangladesh, which hosts the largest Rohingya population - they are ex situ stateless refugees. Therefore, the majority of stateless people globally are in situ stateless ( $75 \%$ of those reported). Many in situ stateless persons belong to national, ethnic, religious and linguistic minorities, and there is an observable correlation between minority groups and the denial or arbitrary deprivation of nationality. ${ }^{47}$ This suggests most in situ statelessness is caused by ethnic discrimination against minorities, ${ }^{48}$ who are often subject to this arbitrary deprivation of nationality. 49

In this regard, the question is whether SDPs could be applicable to in situ statelessness, or to countries with large in situ stateless populations. For example, Latvia and Côte d'Ivoire have the largest in situ stateless populations in the world and have adopted SDPs. ${ }^{50}$ The other question is, could an SDP be applicable to in situ statelessness in a country without a large-scale population of stateless persons?

The Inter-American human rights system, UNHCR and the doctrine in this field are coherent in pointing out that SDPs are not applicable to in situ statelessness, but should be applied in the context of 'persons on the move' (migrants and

45 From approximately 218,000 persons 'potentially stateless or potentially at risk of statelessness' mapped in the United States, 3.2\% have lived in the United States 15-19 years, and $18.2 \%$ have lived in the United States for 20 or more years. Those who have lived in the United States for 20 years or more are mostly from Laos and Thailand and persons from the former Soviet Union and Yugoslavia'. Statelessness in the United States: A Study to Estimate and Profile the US Stateless Population (Report, Center for Migration Studies 2020) 54, 55 $<$ https://cmsny.org/wp-content/uploads/2020/01/StatelessnessReportFinal.pdf $>$.

46 UNHCR has not published statistics concerning statelessness in the Dominican Republic in their Global Trends annual report since 2016. The numbers for people of Haitian descent and their offspring are not clear. At least 61,000 of the affected population are registered in the civil registry; more than 8,000 applied to a special naturalisation process; and, as of 2017 , approximately 75,000 were registered in the foreigners book without nationality, most of them minors. Paola Pelletier, ' 6 Years Since Law 169-14, Billing with Data' ['A 6 años de la Ley 169-14: facturando con datos'], Acento (online, 22 May 2020). $<$ https://acento.com.do/opinion/a-6-anos-de-ley-169-facturando-con-datos-8820205.html $>$.

These numbers are similar to those reported by the Dominican Republic Mission at High Segment level on Statelessness in 2019. General Debate (Cont'd) - 6th Meeting, $70^{\text {th }}$ session of UNHCR Executive Committee (UNHCR 9 October 2019) 2:51:37-2:52:28 $<$ http://webtv.un.org/watch/general-debate-contd-6th-meeting-70th-session-of-unhcrexecutive-committee/6093645658001/?term=>.

47 Special Rapporteur on Minority Issues, Effective Promotion of the Declaration on the Rights of Persons Belonging to National or Ethnic, Religious and Linguistic Minorities. Statelessness: A Minority Issue, UN Doc A/73/205 (20 July 2018) 6 [21].

48 De Jure Statelessness in the Real World, Applying the Prato Summary Conclusions (Report, Open Society, 2011) 5.

49 Guidelines No 3 (n 39) [45].

50 Concerning Latvia, in the Global Trends 2019 (n 42) 74 n 27, the UNHCR number includes figures from two separate laws. Persons determined as stateless under the Law on Stateless Persons (2004) 25 Latvijas Vēstnesis 5 (Latvia) ('Latvian Law on Stateless Persons') number 169 in 2019, while those determined under the Law on Former USSR Citizens (n 24) number 216,682. In conjunction, these figures constitute the total number of 'persons under the statelessness mandate' in the country, which includes 'non-citizens', indicating that 'noncitizens':

enjoy a set of rights and obligations generally beyond the rights prescribed by the 1954 Convention and as such may currently be considered persons to whom the Convention does not apply in accordance with Article 1.2(ii).

See also 'Statelessness Index: Latvia' (n 24). Côte d'Ivoire shows 955,399 'persons under UNHCR's statelessness mandate': Global Trends 2019 (n 42) 73. Statelessness in Numbers: 2020 (n 42) 1 . 
refugees). These current standards do not make a distinction between large scale in situ statelessness or small scale in situ statelessness:

In the case of stateless persons in situ, where there is a realistic prospect of acquisition of citizenship in the near future, it may be inappropriate to conduct a determination of whether they are stateless, in particular where this could delay a durable solution (i.e. the grant of nationality) ... Where stateless persons are present predominantly in their 'own country,' the solution for those individuals in situ will generally be acquisition of the nationality of that country ... For stateless individuals within their own country, as opposed to those who are in a migration context, the appropriate status would be one which reflects the degree of attachment to that country, namely, nationality. ${ }^{51}$

In situ stateless are the largest stateless population in the world and are subject to structural discrimination, especially considering that the majority of in situ stateless population belongs to ethnic and racial minorities. This analysis concludes that naturalisation is not applicable in cases of in situ statelessness, nor are SDPs applicable in cases where nationality of in situ stateless persons is arbitrarily deprived.

On the contrary, the solution for in situ stateless persons is an automatic 'restoration of nationality and compensation ... with retroactive effect to the moment of deprivation' and, if necessary, applying a simple, reasonable and nondiscretionary procedure. ${ }^{52}$ This means that governments should facilitate and make accessible the process of reacquisition, confirmation or restoration of nationality, ${ }^{53}$ returning the rights lost at the moment of deprivation and compensate the affected population with damages. They should also reduce administrative costs and bureaucracy, change 'legislation and policies to reduce or eliminate requirements for the acquisition of nationality', assist stateless persons

51 Geneva Conclusions (n 21) 5:

Where stateless persons are present predominantly in their 'own country', the solution for those individuals in situ will generally be acquisition of the nationality of that country and the State body responsible for citizenship would likely be the most appropriate entity.

See also at Good Practice Paper 2020 (n 3) 2-3:

[f]or stateless populations in a non-migratory context who remain in their 'own country', often referred to as in situ populations, SDPs for the purpose of obtaining status as stateless persons are not optimal because of their long established ties to these countries ... depending on the circumstances of these populations, States are encouraged to undertake targeted nationality campaigns or nationality verification efforts rather than to establish statelessness status through use of an SDP.

Procedures for Determination of Refugees and Statelessness (n 8) 106 [289].

52 Guidelines No 5 (n 28); Human Rights and Arbitrary Deprivation of Nationality (n 28) 15 [14]; Expert Meeting Interpreting the 1961 Statelessness Convention and Avoiding Statelessness Resulting from Loss and Deprivation of Nationality: Summary Conclusions (Report, UNHCR, 2013) [28], [29]; Case of the Girls Yean and Bosico v Dominican Republic (Judgment) (Inter-American Court of Human Rights, Series C 130, 8 September 2005) [142]; Handbook on Protection of Stateless Persons (n 2) [165]; Inter-American Commission on Human Rights, Procedures for Determination of Refugees and Statelessness (n 8) 126 [347].

53 UNHCR Action to Address Statelessness (Report, UNHCR 2010) 15 [50]. $<$ http://www.unhcr.org/refworld/docid/4b9e0c3d2.html>; Handbook on Protection of Stateless Persons (n 2) 30 [58]. 
to meet those requirements, ${ }^{54}$ launch nationality campaigns and advocate for such restoration. 55

Additionally, in contexts where in situ stateless persons are entitled to the right of nationality under national laws, applicants could be forced to apply for naturalisation or residency through special procedures - including through SDP — and can expect to receive 'at the very least, permanent residence with facilitated access to nationality'. ${ }^{56}$ This forced naturalisation may make them a second-class citizen. This is a double victimisation: the applicant's right to nationality is not recognised despite being entitled to it, and they could also be considered 'foreign' or 'stateless' in their own country. 57

Where the applicant has the right to nationality but has no option other than to apply to an SDP as a foreigner in order to access naturalisation, the Inter-American Commission of Human Rights suggests that states 'refrain from impeding access to procedures for determining statelessness status by persons forced to resort to them'. ${ }^{58}$ UNHCR seems to have accepted this solution from a practical and humanitarian perspective and as a last resort: 'practical and humanitarian considerations point towards local solutions through naturalisation'. 59

SDP procedures must be applicable in principle to ex situ stateless populations and, once they are recognised as stateless, the law should facilitate their access to documentation and naturalisation. ${ }^{60}$ In addition, SDPs could be an option for applicants who are in situ stateless but not subject to discrimination. For example, first generation children born in a state that does not recognise jus soli or does not provide a safeguard against statelessness.

54 Statelessness Determination Procedures, Identifying and Protecting Stateless Persons (Report, UNHCR 2014) 4: '[I]t is generally not appropriate to delay solutions for stateless people in these situations by having them apply for recognition as stateless persons through a determination procedure'.

55 Guidelines on Statelessness No 2: Procedures for Determining Whether an Individual is a Stateless Person, UN Doc HCR/GS/12/02 (5 April 2012) [6]-[7] ('Guidelines No 2'), cited by Statelessness Determination (n 37) $5 \mathrm{n} 8$ :

Depending on the circumstances of the populations under consideration, States might be advised to undertake targeted nationality campaigns or nationality verification efforts rather than statelessness determination procedures.

Guidelines No 3 (n 39) [46] n 40; Good Practice Paper 2020 (n 3) 3:

Where States have created stateless populations in their territory, they may well be unwilling to introduce statelessness determination procedures or grant stateless persons the status recommended. In such cases UNHCR's efforts to secure solutions for the population in question may go beyond advocacy to technical advice and operational support for initiatives aimed at recognizing the link between such individuals and the State through the grant of nationality.

56 Guidelines No 3 (n 39) [46]; Procedures for Determination of Refugees and Statelessness (n 8) 127 [348].

57 General Comment 27 (n 41) 20:

The scope of 'his own country' is broader than the concept 'country of his nationality'. It is not limited to nationality in a formal sense, that is, nationality acquired at birth or by conferral; it embraces, at the very least, an individual who, because of his or her special ties to or claims in relation to a given country, cannot be considered to be a mere alien.

58 Procedures for Determination of Refugees and Statelessness (n 8) 127 [350].

59 Guidelines No 3 (n 39) (12).

60 Understanding Statelessness Contexts in Europe (n 38); Procedures for Determination of Refugees and Statelessness (n 8) 156. 


\section{Stateless People Presumed Foreign through SDP Norms.}

According to migration and citizenship norms, as well as in the 23 SDP systems identified for this article, the concept of statelessness extends beyond a 'person without nationality'. As is the case with migrants and refugees, stateless persons are considered aliens, immigrants, foreigners or perceived as 'the other'. Legislation concerning citizenship, immigration, statelessness and SDP describes stateless persons as foreigners, ${ }^{61}$ 'third country nationals', ${ }^{62}$ 'non-nationals' or 'non-citizens', ${ }^{63}$ 'unknown nationality', ${ }^{64}$ 'without nationality' 65 or 'undetermined nationality'. ${ }^{66}$ These classifications result in the segregation of a

61 Spain: Organic Law 8/2000 of 22 December, Reforming Organic Law 4/2000, of 11 January, Regarding the Rights and Freedoms of Foreign Nationals Living in Spain and Their Social Integration (2000) art 34 (Spain): 'The Ministry of Interior shall recognise the statelessness condition to those foreigners that have expressed they have no nationality'. Georgia: Law of the Republic of Georgia on the Legal Status of Aliens and Statelessness Persons (2014) (Georgia) ('Georgian Aliens Law'). The scope of this law is to regulate the legal basis and mechanisms for entry, stay, transit and departure of aliens into/in/through/from Georgia. It also defines the rights and obligations of aliens and stateless persons at art 1(a): 'alien - a person who is not a citizen of Georgia, as well as a person having a status of stateless person in Georgia'. Bulgaria: Law on Foreigners in the Republic of Bulgaria (1998) Prom SG 153, art 2(2) (Bulgaria): 'A foreigner shall also be a stateless person, a person who is not considered a citizen of any country in accordance with its legislation'. Turkey: Law No 6458 'Law on Foreigners and International Protection' (2013) 53(5) Official Journal 28615, art 3(1)(ş) (Turkey) ('Turkish Foreigners Law'): 'Stateless person: a person who does not hold the citizenship of any state and who is considered as foreigner'. Montenegro: Law 01-205/2 'Law of Foreigners' (2018) 24-3 Official Gazette of Montenegro 17-1, art 2 (Montenegro) ('Montenegrin Foreigners Law'): 'a foreigner is a citizen of another state or a stateless person'. Costa Rica: Ley No 8764 de 2009 'Ley General de Migración y Extranjería' [Law No 8764 of 2009 'General Law on Migration and Foreigners'] 170 La Gaceta, art 52 (Costa Rica) ('Costa Rican Migration Law'): 'Las personas extranjeras que pretendan ingresar bajo las categorías especiales, a excepción de las subcategorías de refugiados, apátridas o asilados, requerirán la visa de ingreso correspondiente'. Ecuador: Organic Law on Human Mobility (2017) Supplement Official Registry 938, art 57 (Ecuador): 'Solicitantes de protección internacional. Los solicitantes de protección internacional son las personas extranjeras que solicitan al Estado ecuatoriano ser reconocidas como asiladas, refugiadas o apátridas'. Mexico: Law of Refugees, Political Asylum and Complementary Protection (2011) Federal Official Gazette, art 42 (Mexico). See also Regulation of the Law of Refugees and Complementary Protection (2012) Official Gazette of the Federation (Mexico).

62 Hungary: Act II of 2007 'Admission and Right of Residence of Third-Country Nationals', ch 1 s 2(a) (Hungary) "third-country national" shall mean any person who is not a Hungarian citizen and stateless persons'.

63 Latvian Law on Stateless Persons (n 50) s 3(2): 'A person who is a subject of the law on status of the former USSR citizens who do not have the citizenship of Latvia or that of any other State may not be recognised as a stateless person'.

64 'The Netherlands Violated Child's Right to Acquire a Nationality, UN Committee Finds', United Nations Office of the High Commissioner (Press Release, 29 December 2020) $<$ https://www.ohchr.org/EN/NewsEvents/Pages/DisplayNews.aspx?NewsID=26631\&LangI $\mathrm{D}=\mathrm{E}>$ :

The Human Rights Committee has found that the Netherlands violated a child's rights by registering 'nationality unknown' in his civil records as this left him unable under Dutch law to be registered as stateless and therefore be given international protection as a stateless child.

See also $D Z v$ The Netherlands (n 34): 'States need to determine whether a child would otherwise be stateless as soon as possible so as not to prolong a child's status of undetermined nationality'.

65 Philippines: Commonwealth Act No 613 'The Philippine Immigration Act of 1940', s 13 (Philippines) considers the 'admission of persons without nationality' as admitting immigrants.

66 The term 'undetermined nationality' sometimes differs in meaning to 'stateless' and, in others, is equated with it. For example: 
stateless population from the rest of the society, making them less visible and aggravating their exclusion from their right to nationality.

Non-refugee stateless populations are considered migrants and, given their irregular migratory status based on legislation or state practices, they are normally subject to deportation unless a safeguard is established in the legislation extending the non-refoulement principle from refugees to the stateless. ${ }^{67}$ The extension of non-refoulement principles to non-refugee stateless persons 68 is recommended by international guidance, ${ }^{69}$ but does not have a compulsory character as in refugee law. One indicator is that non-refoulement, as a principle applied to statelessness, has not yet been recognised by international jurisprudence. If a person is

\section{Identification of Statelessness}

(b) Calls on UNHCR to continue to work with interested Governments to engage in or to renew efforts to identify stateless populations and populations with undetermined nationality residing in their territory

(d) Encourages those States which are in possession of statistics on stateless persons or individuals with undetermined nationality... .

UNHCR Conclusion (n 3).

67 Ukraine: Law on Ukrainian Citizenship (2001) art 29(3) (Ukraine):

Foreigners and stateless persons admitted in accordance with the international agreement on readmission, which do not have legal grounds for residing in Ukraine, are subject to forced deportation if there is no agreement on readmission between Ukraine and the country of nationality or country of last permanent residence of foreigners or stateless persons.

See also arts 30,31 .

68 The principle of non-refoulement applied to non-refugee statelessness has been expressly recognised in SDP norms in the Americas and this constitutes good practice. See Costa Rica: Costa Rican Migration Law (n 61) art 4(a); Panama: Executive Decree No 10 of 16 January 2019, CXIII(28696-A) Gaceta Oficial 14 art 6(1) (Panama) ('Panama Executive Decree No 10'). Uruguay: Law No 19.682 'Recognition and Protection of Stateless Persons' (2018) art 6 (Uruguay). Paraguay: Law 6.149 'Protection and Assistance to Enable Naturalisation for Stateless Persons' (2018) 178 Gaceta Oficial De La Republica Del Paraguay 16, art 12 (Paraguay) ('Paraguayan Law No 6.149'). While in Georgia, the non-refoulement benefits the applicant for SDP when they have not been subject to a previous deportation decision, see Georgian Aliens Law (n 61) art 2(2); Ordinance No 523 'Approval of the Procedures for Determining the Status of a Stateless Person in Georgia' (2014) (Georgia) ('Georgian Ordinance No 523'). In Turkey and in Montenegro the applicant shall hold an ID or certificate of statelessness status application. See Turkish Foreigners Law (n 61) art 51(1)(b); Montenegrin Foreigners Law (n 61). In Moldova, the person must be subject to statelessness recognition: Law No 200 of 16 July 2010 on the Regime of Foreigners in the Republic of Moldova, 179-81 Official Gazette of the Republic of Moldova 610, art 63 (Moldova) ('Moldovan Law No 200'), as amended by Law No 284 of 18 December 2011 on Amendment and Completion of Certain Legislative Documents, 30-33 Monitorul Oficial 93, art IV(5) (Moldova) ('Moldovan Law No 284').

69 Non-refoulement applied to non-refugee statelessness has been suggested:

[s]imilarly, where standards of treatment are provided for a complementary form of protection, including protection against refoulement, States must apply these standards to stateless individuals who qualify for that protection.

Guidelines No 3 (n 39) 3 [9] (emphasis in original); Handbook on Protection of Stateless Persons (n 2) 46 [127] [128]. See also 'Non-refoulement. Draft Articles on the Protection of Stateless Persons and the Facilities for Their Naturalisation (Draft Articles, UNHCR, February 2017) [13].

No stateless person or applicant for recognition of such status shall be returned, expelled, extradited or in any way put at the frontier of a territory that may endanger their life, personal safety or freedom. 
'presumed' or 'could be' stateless, where are they going to be deported to? 70 Deportation without due process, without determining if the person is foreign, a refugee, a national or stateless, is contrary to international standards. ${ }^{71}$

Following this reasoning, SDP norms start from the presumption or assumption that applicants seeking statelessness status recognition are foreigners. In this regard, in some countries, the same SDP norms regulate the route to naturalisation once the applicant has been recognised as stateless, while in other countries access to naturalisation is regulated by special laws or decrees from an executive branch. ${ }^{72}$ However, it is possible that an applicant may be a national of the country in which they have applied for a determination of their statelessness - and this will be discussed in the following Part.

\section{What If the Applicant Could Be a National of the Country in}

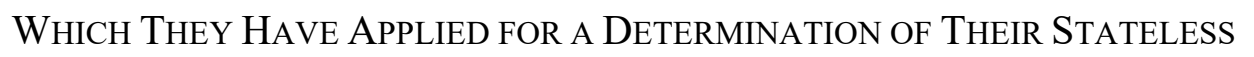

\section{STATUS?}

When an SDP process is conducted, it may be possible to identify applicants who are not stateless, foreigners or immigrants but are instead nationals of the state in which they are applying for stateless status recognition. The applicant may or may not be aware of the links with the relevant country of nationality, but for different reasons ${ }^{73}$ the applicant has decided or is forced to apply for statelessness status recognition. If successful, the door may be open for residency, documentation and naturalisation. The question in this scenario is: what should be done if there is a suspicion $^{74}$ that the applicant could be a national of the state in which they have applied for a determination of their status during an interview, investigation or

70 'The States shall enforce the right of non-refoulement of any person in all places where they exercise jurisdiction, even within their own territory': Organization of American States, InterAmerican Principles on the Human Rights of All Migrants, Refugees, Stateless Persons, and Victims of Human Trafficking that non-refoulement, Res 04/19 (7 December 2019) 6, s 1. See also Process in Procedures for the Determination of Refugee Status and Statelessness (n 8) 53 [125].

71 See Slivenko (n 30) 263 [120]; Mikolenko v Estonia (European Court of Human Rights, Fifth Section, Application No 10664/05, 8 October 2009) [64]-[68]; Auad v Bulgaria (European Court of Human Rights, Fourth Section, Application No 46390/10, 11 October 2011), cited by Strategic Litigation: An Obligation for Statelessness Determination under the European Convention on Human Rights (Report, European Statelessness Network 2014) 6, 10 $<$ https://www.refworld.org/pdfid/582326c34.pdf $>$; Expelled Dominicans and Haitians $v$ Dominican Republic (Judgment) (Inter-American Court of Human Rights, Series C No 282, 28 August 2014) 135 [386], 140 [403]-[404]; American Convention on Human Rights: 'Pact of San José, Costa Rica', opened for signature 22 November 1969, 1144 UNTS 144 (entered into force 27 August 1979) art 22 expressly prohibits deportations of nationals.

72 Lei No 13.445, de 24 De Maio De 2017 'Institui a Lei de Migração' [Law No 13.445, of 24 May 2017 'Instituting the Migration Law'], 99 Diário Oficial Da União 1 (Brazil) Brazil is the only state with an SDP stated in its law, which provides an expedited process for naturalisation. Once the statelessness status has been recognised, the person has the option to apply for naturalisation without prior residence time nor further requirements, arts 26(6), 26(7), 26(8).

73 For example, material reasons, lack of information or evidence or a state policy of denial of citizenship.

74 If the SDP authority identifies that the applicant could be a national of the country to which they are applying for statelessness status recognition, the question arises as to what standard of evidence or standard of proof is needed. This issue will be part of the analysis in Part VI of this article. 
analysis of a case? What SDP norms have been established in this regard? What standard of evidence should be applied? ${ }^{75}$

Within the 23 SDP norms identified for this article, eight countries have expressly incorporated a safeguard within their SDP norms to address cases where the applicant is suspected to be, or identified as, a national of the same country. These countries are: Costa Rica, Panama, Paraguay, Argentina, Turkey, Moldova, Georgia and Ukraine. The following Part discusses and briefly analyses each of them, despite the current challenges of monitoring, reporting and implementing the safeguard articles.

\section{A Costa Rica: Executive Decree No 39620 of 2016 'Regulations for the}

\section{Declaration of the Status of Stateless Persons' ('Decree No 39620') 76}

\section{Article 12 of the Decree No 39620 states:}

The Ministry [of Foreign Affairs] should verify, as soon as possible, if the applicant for statelessness recognition is registered in the civil registry as Costa Rican and that there is no reliable proof that he or she possess another nationality, within a period of no more than 15 business days starting from the date of the opening of the case, the correspondent certification will be issued to Migration and Foreigners Office in order to proceed with the issuance of a provisional document certifying the applicant is under a process of statelessness status recognition.

Decree No 39620 requires the Ministry of Foreign Affairs to 'verify, as soon as possible' with the national civil registry system whether the applicant could be a national of Costa Rica. ${ }^{77}$ This disposition does not rely on the discretion of SDP authorities to conduct a consultation concerning birth registration and nationality - the consultation is compulsory and institutionalised as part of the procedure itself. While the answer from the national civil registry system is pending, and within 15 days from the date of application for statelessness status recognition, the applicant shall receive a provisional document certifying that the application is under a process of statelessness status recognition'. ${ }^{78}$

The legislation is silent on the suspension of the SDP while the answer from the national civil registry system is pending. For this reason, it seems in practice, the response from the civil registry system is expected to be provided in an expedited manner.

75 It is important differentiate between two concepts 'burden of proof' and 'standard of proof':

burden of proof in legal proceedings refers to the question of which party bears the responsibility of proving a claim or allegation ... In the case of statelessness determination, the burden of proof is in principle shared, in that both the applicant and examiner must cooperate to obtain evidence and to establish the facts ... Given the nature of statelessness, applicants for statelessness status are often unable to substantiate the claim with much, if any, documentary evidence ... the standard of proof or threshold of evidence necessary to determine statelessness must take into consideration the difficulties inherent in proving statelessness, particularly in light of the consequences of incorrectly rejecting an application ... finding of statelessness would be warranted where it is established to a 'reasonable degree' that an individual is not considered as a national by any State under the operation of its law ... stateless will not be established to a reasonable degree where the determination authority is able to point to clear evidence that the individual is a national of an identified State.

Handbook on Protection of Stateless Persons (n 2) [89]-[93].

76 Decreto Ejecutivo No 39620 de 2016 'Reglamento para la Declaratoria de la Condición de Persona Apátrida' ['Executive Decree No 39620 of 2016 'Regulations for the Declaration of the Status of Stateless Persons'] (Costa Rica) ('Decree No 39620').

77 ibid art 12.

78 ibid art 4(d). 
Despite this safeguard, Costa Rica does not publish data concerning nationals identified through the SDP and referred to the civil registry system. As of 2020, the official data reported 89 cases that were recognised as stateless and 136 files that remain active. ${ }^{79}$ Costa Rica has a mixed system of nationality acquisition (jus soli and jus sanguinis), nevertheless, the most relevant statelessness situation has been in situ stateless or in situ populations at risk of statelessness. ${ }^{80}$ Thus, it is possible that in situ stateless populations could apply to the SDP and be identified within this procedure.

\section{B Paraguay: Law No 6.149 'Protection and Assistance to Enable Naturalisation for Stateless Persons' ('Law No 6.149') ${ }^{81}$}

Article 52 of Law No 6.149 contains the procedure for late birth registration.

When the National Commission for Stateless and Refugees ('CONARE'), determines, based on the documentation and facts presented on the application or interview, that the person would have been born in the territory of the country without properly nor timely birth registration, the process will be suspended and the case referred to the competent authority to proceed with the late birth registration, accordingly. If this procedure has concluded without the person being registered as a national, an administrative or judicial final decision will be communicated to CONARE to continue the statelessness determination procedure.

Article 65 contains a presumption of nationality. It states that:

no person will be officially considered stateless if, given their disability condition, they cannot be understood by others, through other persons or by other means, and as result, cannot demonstrate they are a national of the country or have a right to nationality of the country. In these cases, CONARE's Executive Secretary will refer the case for verification or grant the nationality, and in cases of doubt will decide in favour of nationality status.

The law relies on CONARE's discretion to identify whether the applicant could be a national of the state and refer the case to the national civil registry system. The civil registry will then investigate if the applicant could be a national of Paraguay.

79 Comisión Interamericana de Derechos Humanos, Lanzamiento del informe sobre debido proceso para la determinación de persona refugiada o apátrida (YouTube, 19 December 2020) 00:28:00-00:35:00<https://www.youtube.com/watch?v=KL_wSC-okjQ>.

80 In Costa Rica, some indigenous populations and their offspring, such as the Ngäbe-Buglé people, who migrated from Panamá to Costa Rica to work on plantations, have been at risk of statelessness given the lack of birth registry. This includes abandoned children. Between 2017-19, 6,300 cases were filed for birth registry in Costa Rica. Costa Rica, in collaboration with Panama, adopted a specialised model for eradicating the risk of statelessness and providing access to civil registries for indigenous populations, especially in border zones. In this regard, Costa Rica made the requirements for access to late birth registration flexible, with a distinct focus on indigenous populations. 'Proyecto 'Chiriticos' benefició a cientos de indígenas Ngäbe-Buglé en Sixaola', UNHCR (Blog Post, 9 August 2017) $<$ https:/www.acnur.org/noticias/noticia/2017/8/5b0c1d5311/costa-rica-proyecto-chiriticosbeneficio-a-cientos-de-indigenas-ngaebe-bugle-en-

sixaola.html\#: :text=Las $\% 20$ personas $\% 20 \mathrm{Ng} \% \mathrm{C} 3 \% \mathrm{~A} 4 \mathrm{be} \% 2 \mathrm{DBugl} \% \mathrm{C} 3 \% \mathrm{~A} 9 \% 2 \mathrm{C} \% 20$ que, no\%20registro\%20de\%201os\%20nacimientos>; Estudio Regional sobre Inscripción Tardía de Nacimientos, Otorgamiento de Documentos de Nacionalidad y Apatridia (Report, UNHCR December 2020) 40, 45, 75, 107.

81 As of December 2019, Paraguay reported that it had not yet received SDP applications. Good Practice Paper 2020 (n 3) 42; Paraguay: Paraguayan Act No 6.149 (n 68). 
The law is silent on the timeframe in which the national civil registry system should conduct the investigation, and there is no provision in the law specifying the procedure at the competent civil registry office. It also seems as if an additional cost will be the burden on the applicant to follow up once the case is referred to the civil registry system. If the applicant is not considered a national by the national civil registry system, the continuation of the SDP depends on prior administrative or judicial processes and CONARE's corresponding notification. If the applicant does not have access to legal assistance, they may face obstacles or delays.

Among the eight countries with SDP norms regarding the identification of nationals, Paraguay is the only country that has specifically regulated the protection of persons with disabilities, also taking into account the situation of persons with psychosocial or mental disability. The Paraguayan SDP orders the referral of these cases for assistance on disability matters. This norm also establishes the mechanism for investigating and verifying that the applicant is a national of the country via the competent civil registry authorities. Nevertheless, the SDP expressly guarantees the right of nationality to persons with disabilities without further delays stating that, 'in case of doubt', 82 a person with a disability will be presumed to be a national of the state.

\section{Panama: Executive Decree No 10 of 16 January 2019 ('Executive Decree}

$$
\text { No } \left.10^{\prime}\right)^{83}
$$

Article 18 of Executive Decree No 10 disposes the request to competent institutions during the registration phase of the SDP application. Following the opening of the file and its registration, the Ministry of Foreign Affairs will immediately send official communications to the National Civil Registry Office and the Electoral Court. The Ministry will also request a certification that the applicant's birth is not registered in the Republic of Panama, that there is no ongoing process occurring in this regard or whether a request for late birth registration has been made and rejected.

Following an application submitted for a determination of statelessness, within the registry phase, the SDP authority shall request the national civil registry office to provide a certification detailing the links the applicant may have with Panama in terms of nationality. The legislation does not provide a deadline for this process.

Articles 29, 30 and 31 of Executive Decree No 10 establish a procedure to register persons identified as nationals in coordination with the national civil registry system and the Electoral Court. If the applicant is identified as a national, the Ministry of Foreign Affairs shall suspend the SDP and refer the case, with the corresponding evidence, to the National Civil Registry Office - an entity that is part of the Electoral Court - to proceed with late birth registration.

The National Civil Registry Office has three months to investigate, receive a declaration from the applicant and decide whether to proceed with the late birth registration. If the National Registry Civil Office proceeds with the late birth registration and, therefore, the recognition of nationality, it shall send the birth certificate to the Ministry of Foreign Affairs to conclude the SDP. Conversely, if the applicant is found not to be a national, the National Registry Civil Office shall

82 See Paraguayan Act No 6.149 (n 68) arts 62-65.

83 Panama Executive Decree No 10 (n 68). 
notify the Ministry of Foreign Affairs of the rejection of citizenship and send the file to reactivate the SDP.

\title{
D Argentina: Law No 27.512 'Recognition and Protection of Statelessness
}

\author{
Persons' ('Law No 27.512') 84
}

Article 49 of Law No 27.512 states that:

when the National Commission for Refugees ('CONARE') determines, based on the documentation presented and the events argued in the application or interview, the person would have been born in Argentinian territory without a timely birth registry, the statelessness determination procedure will be suspended and the case will be communicated to the correspondent civil registry authority to proceed with the late birth registration. If the late birth registration procedure concludes without the person being registered as a national, the administrative or judicial decision will be communicated to CONARE to continue with the SDP.

Argentina relies on CONARE's discretion to determine whether to conduct a consultation and, accordingly, whether to proceed with the suspension of the SDP in cases where the applicant may be an Argentinian national. The decision is made according to the evidence available, either during the application phase or after the interview is conducted.

The law does not provide a timeframe for the national civil registry system to respond to CONARE's request, nor a timeframe in which to decide if the applicant has a right to nationality and late birth registration. Despite the gaps in this law, it requires the SDP to continue if the applicant is not registered in the civil registry. However, the law requires that CONARE receive a notification through a final judicial or administrative decision rejecting the applicant as a national of the country. This notification triggers the reactivation of the SDP, however, it involves time and costs for the applicant to follow up procedures in different jurisdictions, which often require the applicant to seek legal assistance.

\section{E Moldova: Law No 200 of 16 July 2010 on the Regime of Foreigners in the}

\section{Republic of Moldova ('Law No 200') 85}

Article 87 of Law No 200 contains provisions for the rejection of the application for the recognition of stateless status. Article $87^{1}(1)(\mathrm{e})$ states that the application for the recognition of stateless status may be rejected if the applicant holds the citizenship of the Republic of Moldova or of another state.

This law does not contain any disposition regulating the consultation and suspension of the SDP in cases where there is a possibility that the applicant could be a national of Moldova. The applicant must wait until the SDP ends and the application rejected on the basis that the authority considers the applicant not stateless but, rather, a national of Moldova. The authority is allocated six months to one year to decide the application under art $87^{2}(1)$. However, if the process presents delays, in practice, the applicant would not have access to national recognition nor documentation. The law does not specify what process should be

84 Ley General No 27.512 'Reconocimiento y Protección de las Personas Apátridas' [ 'General Law No 27.512 'Recognition and Protection of Statelessness Persons'] (2019) Boletín Oficial (Argentina) ('Argentinian Law 27.512').

85 Moldovan Law No 200 (n 68). 
followed if the applicant is rejected based on the applicant not being stateless and, therefore, has the right to apply for Moldovan citizenship at the corresponding national civil registry system.

Moldova reported to UNHCR that, between 2011 and December 2019, 355 out of 1,144 applicants (31\%) were recognised as stateless. UNHCR reported the following:

[i]t is noteworthy that among the 279 (24\%) individuals whose applications were rejected, some were rejected on the basis that they were eligible to apply for Moldovan citizenship and were therefore subsequently directed to the appropriate government institution. Many of these applicants were ultimately granted Moldovan nationality. ${ }^{86}$

In practice, the authority informs the applicant what process should be followed if the application is rejected. Generally, the process will be to apply for citizenship with the corresponding institution. ${ }^{87}$ It is unclear in the referred report how many of the $24 \%$ of rejected applications were eligible to apply for Moldovan nationality, however, this information indicates that Moldova has statistical data specifically concerning these cases. This reporting contributes to the visibility of in situ statelessness in SDP official statistics, and also constitutes an example of good practice for further public policies and decisions to be developed.

\section{F Georgia: Ordinance No 523 'Approval of the Procedures for Determining the Status of a Stateless Person in Georgia' ('Ordinance No 523') 88}

Article 6 of Ordinance No 523 contains the procedure for reviewing applications. Article 6(1) states:

if the applicant does not have identification or travel documents, the Agency shall determine the identity of the applicant. To determine valid details about the applicant, the Agency shall request and obtain from Georgian and/or foreign authorized bodies, civil registration records and/or records or information concerning the issuance of the applicant's identification documents. If the Agency fails to obtain such data/record/information, the person's identity may be verified by written information provided by the corresponding authority of the State or local self-government body, medical or educational institution, or from an international or non-governmental organization, as well as by notarised written information submitted by two persons of full age and capacity.

Article 10 contains the grounds for refusing statelessness status determination. According to art 10(a) 'statelessness status recognition may be refused if it has been established that the applicant has Georgian or foreign citizenship' ${ }^{89}$

86 From this information it can be concluded that $510(46 \%)$ of the cases were rejected. See the report provided by Moldova in Good Practice Paper 2020 (n 3) 37.

87 ibid.

88 Georgian Ordinance No 523 (n 68), which replaced Georgian President's Decree No 515 'Approving the Rules for Stateless Status Determination' (2012) (Georgia).

89 The same disposition is contained in Georgian Ordinance No 523 (n 68) art 23:

Article 23 - Grounds for refusing to determine the status of stateless persons and for termination of statelessness status:

1. An applicant may be denied the determination of the status of stateless person in Georgia if:

(a) it is determined that he/she is a citizen of Georgia or of a foreign state. 
When the applicant does not have an ID, inquiries to relevant local institutions, including the national civil registry, are made as part of due diligence in the SDP investigation phase. Like Moldova, the applicant must wait until the SDP ends which may take six to nine months according to the law 90 - before they are notified of the decision rejecting the application on the basis that they are not stateless but, instead, have the right to Georgian citizenship.

\section{G Turkey: Implementing Regulation on Foreigners and International} Protection ('Regulation on Foreigners and International Protection') 91

In Turkey, determination of statelessness occurs under art 49(3) of the Regulation on Foreigners and International Protection. Article 49(3) provides that:

investigations shall be carried out to determine whether the foreigners are among the 'unrecorded population' by contacting the relevant provincial/district directorates of civil registration and citizenship where there is a question of whether the applicant may be among the 'unrecorded population..$^{92}$

It can be elucidated that the SDP norm considers those who could be nationals as an 'unrecorded population' or unregistered. In the case of 'doubt' regarding whether the applicant is a national, the application rules grant the SDP discretion to conduct an investigation in consultation with national sources, such as local or national civil registry offices. The Regulation is silent on the timing of the investigation and what should be done if the applicant is identified as a national of the country. It is unclear whether the SDP would be suspended or filed, or if the applicant would have to wait until a final decision rejecting the application based on the applicant's entitlement to citizenship.

H Ukraine: Law of Ukraine on Amending Certain Legislative Acts of Ukraine Regarding Recognition as a Stateless Person ('Ukraine Statelessness

\section{Amendment Law') ${ }^{93}$}

Article $6^{1}(2)$ of the Ukraine Statelessness Amendment Law governs the recognition of applicants as stateless persons. It states that:

[i]f any circumstances demonstrating the applicant's eligibility for the Ukrainian citizenship as per the Law of Ukraine on Citizenship of Ukraine arise during the procedure of recognition as a stateless person, review of the application on recognition as stateless person shall be suspended until completion of verification of belonging to the Ukrainian citizenship. Depending on the outcomes of such verification the review of the application on recognition as a stateless person shall be renewed or ceased.

According to art $6^{1}(3)$ :

90 Georgian Ordinance No 523 (n 68) art 8(2).

91 Implementing Regulation on Foreigners and International Protection (2016) 29656 Official Journal (Turkey) ('Turkish Implementing Regulation').

92 The SDP norm considers those who could be nationals as part of the 'unrecorded population'. See ibid art 49(3).

93 Law of Ukraine on Amending Certain Legislative Acts of Ukraine regarding Recognition as a Stateless Person (2020) (Ukraine) ('Ukraine 2020 Statelessness Amendment'). This law amended the Law of Ukraine on the Legal Status of Foreigners and Stateless Persons (1994) (Ukraine). 
Decision on refusal in recognition as a stateless person shall be made by the State Migration Service ... if the applicant is a citizen of Ukraine or another State, provided that his/her citizenship was recognized by the competent authority of this State and the applicant was documented according to this State's legislation.

The law relies on the discretion of SDP authorities to suspend the process for the investigation or verification of whether the applicant is a citizen of Ukraine. The law does not establish a timeline for this investigation, nor for the suspension of the procedure. However, it states that, conditional on the outcome of such investigation, the SDP shall continue or end by filing the case.

As in Georgia and Moldova, the applicant shall wait until the SDP ends, rejecting the statelessness status application, or rejecting the application because the applicant is entitled to Ukrainian citizenship, or recognize the statelessness status. In this matter, the closing or filing of the case requires a final decision from the SDP authority rejecting the application since the applicant is eligible for citizenship.

\section{Commentary on The SAFEguards against the Presumption That}

\section{SDP APPLICANTS ARE FOREIGN}

SDP laws, measures or norms are part of administrative law, and the judicial review of these procedures shall be part of due process. The possibility that the applicant of the SDP may be a national of the country in which they have applied for the procedure may arise during the registration, interview or analysis phases of the SDP. ${ }^{94}$ The eight SDP systems discussed above do not establish which standard of evidence applies when there is suspicion or doubt that the applicant could be national of that state. However, as in RSD, the standard of evidence for SDP is shared between the authority and the applicant. It is enough for the standard of proof to be to a 'reasonable degree' 95 to determine that the applicant is stateless. ${ }^{96}$ Therefore, the same standard of proof could be applicable to SDP norms, which have granted authorities discretion over the identification of nationals and the corresponding consultations with national civil registry systems.

Nevertheless, consultations and inquiries to national civil registry systems should be considered good practice as long as the discretion to refer a case to these systems is not left to SDP authorities. Costa Rica and Panama, for example, have established a compulsory inquiry to the national civil registry system as part of their SDP. In this manner, the presumption that the applicant is foreign is questioned. These safeguards in SDP norms guarantee the right to nationality and expedite access to the civil registry system, rather than consigning applicants to face delays.

Applicants who must wait until the end of the procedure (the final decision or resolution of the case) are left unprotected, as a result of the delays that occur in

94 The 23 SDP norms analysed for this article establish similar procedural phases to RSD: 1. application or registration; 2 . interview; 3 . analysis of the case; and 4. decision.

95 '[S]tatelessness will not be established to a reasonable degree where the determination authority is able to point to clear evidence that the individual is a national of an identified State'. Handbook on Protection of Stateless Persons (n 2) [89]-[93].

96 The majority of the 23 SDP norms examined for this article follow this standard of proof or standard of evidence. Despite some countries in Europe not expressly stating this standard in their SDP, it seems that, in practice, it is followed. However, the SDP adopted in the Americas expressly state the same standard of proof. See Handbook on Protection of Stateless Persons (n 2) 34-35 [89]-[93]; Good Practice Paper 2020 (n 3) 16-18. 
practice. It is important that SDP norms are strengthened and designed to fill the gaps by indicating a timeframe for the referral of cases and the issuance of a decision between the SDP authority and the national civil registry system, as well as by clarifying how the inter-institutional coordination between them will operate. An express deadline established in the norm, by which the SDP authority must refer the case to the national civil registry system, constitutes a guarantee on behalf of the applicant. However, the civil registry system or the competent authority in this matter should also have an express timeframe established in the SDP norm in which they must answer the request from the SDP authority and proceed accordingly.

SDP norms from Costa Rica, Panama, Paraguay and Argentina (the Americas) constitute good practice for cases when the applicant may be a national of the country in which they have applied for a determination of their status. These norms expressly indicate the suspension of the SDP while the final investigation takes place at a national civil registry system. When the SDP authorities receive the conclusive decision from the civil registry or competent authority, the SDP process shall continue or conclude by filing the case.

However, it is important to include a safeguard expressly written in the norm in cases of omission or lack of answer from any authority. Such a safeguard would allow the applicant to take legal action or seek a remedy (either administrative or judicial) against administrative delays and reactivate the SDP process. Nevertheless, placing the obligation on the applicant to push the proceedings forward in the SDP and civil registry system constitutes a prejudicial burden on the applicant in terms of cost and time. Also, it is important to take into consideration the special vulnerabilities of the applicant and the challenges faced accessing free legal assistance.

On the other hand, the decision issued by the SDP authority rejecting the application would not recognise the right to nationality as a result of the SDP process, since the competent jurisdiction to decide on this matter is the national civil registry system. However, this administrative decision issued by the SDP authority rejecting statelessness recognition is itself recognition of the person's entitlement to nationality. The applicant could then claim the nationality at the corresponding national civil registry authority or jurisdiction. In other words, a decision issued by the SDP authority rejecting an applicant on the basis that they are 'eligible' for citizenship of the state in which have applied for a determination of statelessness, constitutes official evidence of the applicant's right to citizenship and, therefore, they are not stateless.

When the applicant has official knowledge that the application for statelessness status recognition has been rejected and they must pursue a citizenship process at a national civil registry system, it is important to ensure there are appropriate procedures for late birth registration. In this situation, a simple, flexible and expedited special procedure for the validation or recognition of nationality ${ }^{97}$ and late birth registration should be expressly established through administrative norms issued by the national civil registry system, taking into consideration special vulnerabilities. This would avoid applicants being subject to the requirements for ordinary late birth registration and procedures. ${ }^{98}$ Especially

97 Good Practice Paper 2020 (n 3) 3; Guidelines No 2 (n 55) [6]-[7].

98 Handbook on Protection of Stateless Persons (n 2) 26 [61]: 
regarding the late birth registry of children, these administrative norms should include an expedited registry of applicants' children or descendants. ${ }^{99}$

\section{CONCLUSION}

Certainly, nationality is considered to be a stateless person's happy ending. Naturalisation, a citizenship granted by states to those considered foreigners or immigrants, is one of the main goals of SDP norms. This is both for protection purposes and because naturalisation definitively facilitates the applicant's integration into the society. SDP norms assume or presume that applicants are foreigners, and once recognised as stateless as a result of this process, they should have a route to access documentation (ID and residence) and naturalisation.

SDP applicants must be within the territory of the state to present their application. ${ }^{100}$ However, international standards recommend that SDPs are not applicable to in situ stateless. This population has largely been born in, or have strong links with, the territory, and are likely entitled to the right to nationality by constitution or law. Despite accurate statistics on statelessness remaining a challenge, it has been determined that most in situ stateless peoples in the world belong to discriminated minority groups, who are arbitrarily deprived of citizenship by acts and omissions of the state. In these cases, the remedy or solution is the immediate restoration and 'validation of nationality' through law, judicial and administrative measures, documentation and the effective enjoyment and exercise of nationality rights.

SDPs should not be used as a political tool by states. Stateless people who have the right to nationality must not be forced to apply to an SDP to be granted a second-class citizenship though a naturalisation formula. This allows governments to maintain a continuous threat of stripping the nationality granted by naturalisation. Therefore, SDPs should neither be applicable to prima facie or collective statelessness recognition in contexts of structural discrimination of minority groups.

Express dispositions in SDP laws or norms concerning procedures for cases where an applicant could be identified as a national of the country raise a 'red flag' against the presumption that SDP applicants are foreigners. The safeguards on SDP norms identified in Costa Rica, Paraguay, Panama, Argentina, Georgia,

The procedural requirements of both nationality campaigns and nationality verification procedures will be similar to those used in statelessness determination procedures in practice, as they need to reflect the forms of evidence available in a country and the difficulties faced by applicants in proving their nationality status.

99 See ICCPR (n 41) art 24(2); Convention on the Rights of the Child, opened for signature 20 November 1989, 1577 UNTS 3 (entered into force 2 September 1990) arts 3(1), 3(2), 7(1) and 7(2), also signed by the 23 SDP countries identified for this article. The special procedure on late birth registration shall also ensure citizenship acquisition.

Birth registration is the permanent recording of a child's existence and does not confer nationality. Nationality is acquired through the operation of a State's nationality law. The two processes are distinct. Nonetheless, birth registration helps to prevent statelessness because it establishes a legal record as to where a child was born and who his/her parents are, elements of information key to proving entitlement to nationality.

Good Practice Papers, Action 7 (Ensuring Birth Registration for Prevention of Statelessness) (Report, UNHCR 2017) 3. See also ‘\#IBelong Campaign’ (n 4): Action 2: Ensure that no child is born stateless, Action 3: Remove gender discrimination from nationality laws, and Action 8: Issue nationality documentation to those with entitlement to it.

100 The 23 SDP norms identified for this article require that the applicant shall be within the boundaries of the state; if the applicant is in the border, as refugee international standards, the state shall facilitate the access to SDP. 
Moldova, Ukraine and Turkey constitute a good practice that should be recognised, used as guidance and reinforced through further modifications of current SDP norms, implementation rules or future SDP norms adopted by states.

The national civil registry system or the relevant competent authority on citizenship should have the last word on citizenship, in close coordination with the institution that conducts the SDP. Inter-institutional consultations at a national level and any administrative or judicial decision must be done without delays and should adopt a differentiated approach when applicants present vulnerabilities, such as children or persons with disabilities. An expedited mechanism on behalf of the applicant between the jurisdiction where the SDP takes place and the national civil registry system still constitutes a challenge, unless both jurisdictions and competencies are assigned by law to one state entity or agency.

In addition, express safeguards on SDP legislation, such as those analysed in this article, break with the presumption that the applicant is foreign and constitute a legal basis for official statistics. The data of applicants who could be nationals of the state identified through an official SDP mechanism should be published by the civil registry system and by the authority that conducts the SDP. This information would benefit the analysis of decision makers on policies concerning nationality and statelessness.

Finally, states must ensure that the recognition of nationality is the first and fastest road towards ending statelessness. Supporting state policies which move towards naturalisation, instead of recognising the right to nationality for those entitled to it, constitutes a symptom of a sickness not yet eradicated. Therefore, naturalisation as a political, humanitarian or pragmatic solution against statelessness should be avoided or adopted as a last resort. 


\section{TABLE OF SDP LAWS}

\section{A Americas}

\begin{tabular}{|c|c|c|c|c|c|}
\hline Country & $\begin{array}{c}\text { Organic Law that } \\
\text { Makes Reference } \\
\text { to Statelessness }\end{array}$ & Year & $\begin{array}{c}\text { SDP: Law/ } \\
\text { Executive Branch } \\
\text { Decree, Resolution } \\
\text { or Application } \\
\text { Rules } \\
\end{array}$ & Year & $\begin{array}{c}\text { SDP } \\
\text { Express } \\
\text { Reference } \\
\text { to Civil } \\
\text { Registry } \\
\end{array}$ \\
\hline Mexico & $\begin{array}{l}\text { Law of Refugees, } \\
\text { Political Asylum } \\
\text { and } \\
\text { Complementary } \\
\text { Protection }\end{array}$ & $\begin{array}{l}2011, \\
\text { amdt in } \\
2016 .\end{array}$ & $\begin{array}{l}\text { Regulation of the } \\
\text { Law of Refugees } \\
\text { and } \\
\text { Complementary } \\
\text { Protection }\end{array}$ & $\begin{array}{l}2012, \\
\text { amdt in } \\
2014\end{array}$ & No \\
\hline Costa Rica & $\begin{array}{l}\text { Law No } 8764 \text { of } \\
2009 \text { 'General Law } \\
\text { on Migration and } \\
\text { Foreigners' }\end{array}$ & 2010 & $\begin{array}{l}\text { Executive Decree } \\
\text { No } 39620 \text { of } 2016 \\
\text { 'Regulations for the } \\
\text { Declaration of the } \\
\text { Status of Stateless } \\
\text { Persons' }\end{array}$ & 2016 & Yes $^{101}$ \\
\hline Brazil & $\begin{array}{l}\text { Law No 13.445, of } \\
24 \text { May } 2017 \\
\text { 'Instituting the } \\
\text { Migration Law' }\end{array}$ & 2017 & $\begin{array}{l}\text { Decree No 9.199, of } \\
20 \text { November 2017 } \\
\text { 'Regulating Law } \\
\text { 13.445, of May 24, } \\
\text { 2017, Which } \\
\text { Instituted the } \\
\text { Migration Law' }\end{array}$ & 2017 & No \\
\hline Ecuador & $\begin{array}{l}\text { Organic Law on } \\
\text { Human Mobility }\end{array}$ & 2017 & $\begin{array}{l}\text { 1. Organic Law on } \\
\text { Human Mobility } \\
\text { 2. Executive Order } \\
\text { No } 111 \text { 'Regulation } \\
\text { of the Organic Law } \\
\text { on Human } \\
\text { Mobility'102 } \\
\text { 3. Executive Order } \\
\text { No 000150 } \\
\text { 'Instructive for the } \\
\text { Process of } \\
\text { Determining Status } \\
\text { of Refugees and } \\
\text { Stateless person in } \\
\text { Ecuador' } 103\end{array}$ & 2017 & No \\
\hline Paraguay & - & - & $\begin{array}{l}\text { Law } 6.149 \\
\text { 'Protection and } \\
\text { Assistance to } \\
\text { Enable } \\
\text { Naturalisation for } \\
\text { Stateless Persons' }\end{array}$ & 2018 & Yes 104 \\
\hline Uruguay & - & - & $\begin{array}{l}\text { Law No } 19.682 \\
\text { 'Recognition and }\end{array}$ & 2018 & No \\
\hline
\end{tabular}

101 Decree No 39620 (n 76) art 12.

102 (2018) 55 Registro Oficial 1 (Ecuador).

103 (2018) 156 Registro Oficial 5 (Ecuador).

104 Paraguayan Law No 6.149 (n 68) arts 52, 65. 


\begin{tabular}{|l|l|l|l|l|l|}
\hline & & & $\begin{array}{l}\text { Protection of } \\
\text { Stateless Persons' }\end{array}$ & & \\
\hline Panama & - & - & $\begin{array}{l}\text { Executive Decree } \\
\text { No 10 of 16 } \\
\text { January 2019 }\end{array}$ & 2019 & Yes 105 \\
\hline Argentina & - & - & $\begin{array}{l}\text { Law No 27.512 } \\
\text { 'Recognition and } \\
\text { Protection of } \\
\text { Statelessness } \\
\text { Persons' }\end{array}$ & 2019 & \\
& & & Yes & \\
& & & & \\
\hline
\end{tabular}

B Europe

\begin{tabular}{|c|c|c|c|c|c|}
\hline Country & $\begin{array}{l}\text { Organic Law that } \\
\text { Makes Reference } \\
\text { to Statelessness }\end{array}$ & Year & $\begin{array}{c}\text { SDP: Law/ } \\
\text { Executive Branch } \\
\text { Decree, Resolution } \\
\text { or Application } \\
\text { Rules }\end{array}$ & Year & $\begin{array}{c}\text { SDP } \\
\text { Express } \\
\text { Reference } \\
\text { to Civil } \\
\text { Registry } \\
\end{array}$ \\
\hline France & $\begin{array}{l}\text { Code of Entry and } \\
\text { Stay of Foreigners } \\
\text { and the Right of } \\
\text { Asylum } 107\end{array}$ & $\begin{array}{l}1952 \\
\text { and } \\
\text { subseq } \\
\text { uent } \\
\text { amend } \\
\text { ments. }\end{array}$ & $\begin{array}{l}\text { 1. Code of Entry } \\
\text { and Stay of } \\
\text { Foreigners and the } \\
\text { Right of Asylum } \\
\text { 2. Decree No } 2015 \text { - } \\
\text { 1166 of September } \\
21,2015 \text { Issued for } \\
\text { the Application of } \\
\text { Law No } 2015-925 \\
\text { of July } 29,2015 \text { on } \\
\text { the Reform of the } \\
\text { Right to Asylum } 108\end{array}$ & 2015 & No \\
\hline Italy & $\begin{array}{l}\text { Law No } 91 \text { of } 5 \\
\text { February } 1992\end{array}$ & 1992 & $\begin{array}{l}\text { Decreto del } \\
\text { Presidente della } \\
\text { Repubblica } 12\end{array}$ & 1994 & No \\
\hline
\end{tabular}

105 Panama Executive Decree No 10 (n 68) arts 18, 29, 30, 31.

106 Argentinian Law 27.512 (n 84) art 49.

107 Code de l'entrée et du séjour des étrangers et du droit d'asile [Code of Entry and Stay of Foreigners and the Right of Asylum] (France) L8120-1-L812-8 ("French Code of Entry and Stay'), created by Loi No 2015-925 du 29 juillet 2015 relative à la réforme du droit d'asile [Law No 2015-925 of July 29, 2015 on the Reform of the Right to Asylum], 0174 JORF (France). The French Code of Entry and Stay was adopted by the Parliament and amended by Ordonnance No 45-2658 du 2 novembre 1945 relative a l'entree et au sejour des etrangers en france et portant creation de l'office national d'immigration [Ordinance No 45-2658 of November 2, 1945 Relating to the Entry and Stay of Foreigners in France and Establishing the National Immigration Office], 259(4) JORF 7223 (France). After 1952, Loi No 2003-1176 du 10 décembre 2003 modifiant la loi no 52-893 du 25 juillet 1952 relative au droit d'asile (1) [Law No 2003-1176 of December 10, 2003 Amending Law No 52-893 of July 25, 1952 Relating to the Right to Asylum (1)], 86 JORF 1 (France) modified the 1952 law and it entered in force in 2004. French Code of Entry and Stay has had different modifications until its current version which was enacted in 2021.

108 Décret No 2015-1166 du 21 septembre 2015 pris pour l'application de la loi no 2015-925 du 29 juillet 2015 relative à la réforme du droit d'asile [Decree No 2015-1166 of September 21, 2015 Issued for the Application of Law No 2015-925 of July 29, 2015 on the Reform of the Right to Asylum], 0174 JORF (France). These modifications in 2015 to the French Code of Entry and Stay (n 107) introduced the SDP in France. 


\begin{tabular}{|c|c|c|c|c|c|}
\hline & $\begin{array}{l}\text { 'New Norms on } \\
\text { Citizenship'109 }\end{array}$ & & $\begin{array}{l}\text { Ottobre } 1993 \text { No } \\
572 \text { 'Regolamento } \\
\text { di Esecuzione della } \\
\text { Legge } 5 \text { febbraio } \\
1992, \text { No } 91 \text {, } \\
\text { Recante Nuove } \\
\text { Norme sulla } \\
\text { Cittadinanza'110 }\end{array}$ & & \\
\hline Spain & $\begin{array}{l}\text { Organic Law } \\
8 / 2000 \text { of } 22 \\
\text { December, } \\
\text { Reforming Organic } \\
\text { Law 4/2000, of } 11 \\
\text { January, Regarding } \\
\text { the Rights and } \\
\text { Freedoms of } \\
\text { Foreign Nationals } \\
\text { Living in Spain and } \\
\text { Their Social } \\
\text { Integration }\end{array}$ & 2000 & $\begin{array}{l}\text { Royal Decree } \\
865 / 2001 \text { of } 20 \text { July } \\
\text { Approving the } \\
\text { Regulation for the } \\
\text { Recognition of the } \\
\text { Status of Stateless } \\
\text { Persons } 111\end{array}$ & 2001 & No \\
\hline Latvia & $\begin{array}{l}\text { 1.Citizenship } \\
\text { Law }^{112} \\
\\
\text { 2. Law on the } \\
\text { Status of Those } \\
\text { Former USSR } \\
\text { Citizens Who Are } \\
\text { Not Citizens of } \\
\text { Latvia or Any Other } \\
\text { State }\end{array}$ & $\begin{array}{l}1994, \\
\text { amdt in } \\
2013 \\
1995\end{array}$ & $\begin{array}{l}\text { 1. Law on } \\
\text { Statelessness } \\
\text { Persons } \\
\text { 2. Regulations of } \\
\text { the Cabinet of } \\
\text { Ministers No 976, } \\
\text { 'Procedures for } \\
\text { Recognizing a } \\
\text { Stateless or Non- } \\
\text { Citizen Child Born } \\
\text { in Latvia after } \\
\text { August } 21,1991 \text { as } \\
\text { a Latvian } \\
\text { Citizen'113 }\end{array}$ & $\begin{array}{l}2004 \\
\text { amdt in } \\
2013 \\
2013\end{array}$ & No \\
\hline Hungary & $\begin{array}{l}\text { Act LV of } 1993 \\
\text { 'Hungarian } \\
\text { Citizenship'114 }\end{array}$ & 1993 & $\begin{array}{l}\text { 1. Act II of } 2007 \\
\text { 'Admission and } \\
\text { Right of Residence } \\
\text { of Third-Country } \\
\text { Nationals'. } \\
\text { 2. Decree 114/2007 } \\
\text { (V 24) } \\
\text { 'Implementation of }\end{array}$ & $\begin{array}{l}2007 \\
\text { amdt in } \\
2019 \\
2007\end{array}$ & No \\
\hline
\end{tabular}

109 Law No 91 of 5 February 1992 'New Norms on Citizenship' (Italy).

1102 Gazzetta Ufficiale (Italy).

111 Real Decreto No 865/2001, de 20 de julio, por el que se Aprueba el Reglamento de Reconocimiento del Estatuto de Apátrida [Royal Decree 865/2001 of 20 July Approving the Regulation for the Recognition of the Status of Stateless Persons] (Spain).

112 (1994) 93 Latvijas Vēstnesis (Latvia). See also The Regulations of the Cabinet of Ministers No 974 'Procedures for Registering a Person as a Latvian Citizen' (2013) 191 Latvijas Vēstnesis (Latvia).

113 (2013) 191 Latvijas Vēstnesis (Latvia). See also Regulations of the Cabinet of Ministers No 1001 'Procedures for Receiving and Examining Application for Naturalisation' (2013) 191 Latvijas Vēstnesis, art 5 (Latvia). Additionally, the Parliament of Latvia adopted a new law in 2019 for children born after 1 January 2020: On the Termination of the Granting of the Status of a Non-Citizen to Children (2019) 224 Latvijas Vēstnesis, art 5 (Latvia).

114 (Hungary). 


\begin{tabular}{|c|c|c|c|c|c|}
\hline & & & $\begin{array}{l}\text { Act II of } 2007 \text { on } \\
\text { the Admission and } \\
\text { Right of Residence } \\
\text { of Third-Country } \\
\text { Nationals, } 115\end{array}$ & & \\
\hline Moldova & $\begin{array}{l}\text { 1. Law No } 200 \text { of } 16 \\
\text { July } 2010 \text { on the } \\
\text { Regime of } \\
\text { Foreigners in the } \\
\text { Republic of } \\
\text { Moldova } \\
\text { 2. Law No } 284 \text { of } \\
18 \text { December } 2011 \\
\text { on Amendment and } \\
\text { Completion of } \\
\text { Certain Legislative } \\
\text { Documents }\end{array}$ & $\begin{array}{l}2010 \\
\text { amdt in } \\
2011 \\
\\
2011\end{array}$ & $\begin{array}{l}\text { 1.Law No } 200 \text { of } 16 \\
\text { July } 2010 \text { on the } \\
\text { Regime of } \\
\text { Foreigners in the } \\
\text { Republic of } \\
\text { Moldova } \\
\text { 2. Law No } 284 \text { of } \\
\text { 18 December } 2011 \\
\text { on Amendment and } \\
\text { Completion of } \\
\text { Certain Legislative } \\
\text { Documents } 116\end{array}$ & $\begin{array}{l}2010 \\
\text { amdt in } \\
2011 \\
\\
2011\end{array}$ & Yes $^{117}$ \\
\hline $\begin{array}{l}\text { United } \\
\text { Kingdom }\end{array}$ & $\begin{array}{l}\text { Immigration } \\
\text { Rules } 118\end{array}$ & $\begin{array}{l}2013, \\
\text { amdt in } \\
2019\end{array}$ & $\begin{array}{l}\text { Immigration } \\
\text { Rules }^{119} \\
\text { Stateless Leave } 120\end{array}$ & $\begin{array}{l}2013, \\
\text { amdt in } \\
2019 \\
2019\end{array}$ & No \\
\hline Georgia & $\begin{array}{l}\text { 1. Organic Law of } \\
\text { Georgia on } \\
\text { Georgian } \\
\text { Citizenship } 121 \\
\text { 2. Law of the } \\
\text { Republic of } \\
\text { Georgia on the } \\
\text { Legal Status of } \\
\text { Aliens and } \\
\text { Statelessness } \\
\text { Persons }\end{array}$ & 2014 & $\begin{array}{l}\text { Ordinance No } 523 \\
\text { 'Approval of the } \\
\text { Procedures for } \\
\text { Determining the } \\
\text { Status of a Stateless } \\
\text { Person in Georgia' }\end{array}$ & 2014 & Yes $^{122}$ \\
\hline Kosovo & $\begin{array}{l}\text { 1.Law No 04/L-215 } \\
\text { 'Citizenship of } \\
\text { Kosovo'123 } \\
\text { 2.Law No 04/L-219 } \\
\text { Foreigners' } 124\end{array}$ & $\begin{array}{l}2015 \\
2013\end{array}$ & $\begin{array}{l}\text { Administrative } \\
\text { Instruction (MIA) } \\
\text { No 06/2020 for the } \\
\text { Procedure and } \\
\text { Criteria of } \\
\text { Determining the } \\
\text { Status of the } \\
\text { Stateless Person, } \\
\text { the Manner of }\end{array}$ & $\begin{array}{l}2015 \\
\text { modifie } \\
\text { d in } \\
2020\end{array}$ & No \\
\hline
\end{tabular}

115 (Hungary).

116 Moldovan Law No 284 (n 68) amends the following laws: Law No 275 of 10 November 1994 'Law on Legal Status of Foreign Citizens and Stateless Persons in the Republic of Moldova, Official Gazette of the Republic of Moldova (Moldova); Law No 1024-XIV on Citizenship of the Republic of Moldova (2000) 98 Official Gazette of the Republic of Moldova 709 (Moldova); Moldovan Law No 200 (n 68).

117 Moldovan Law No 200 (n 68) art 87.

118 (1994) pt 14 'Stateless Persons' (United Kingdom).

119 ibid.

120 Stateless Leave (Guidance Version 3.0, UK Home Office 30 October 2019).

121 (Georgia).

122 Georgian Ordinance No 523 (n 68) arts 6, 10; Georgian Aliens Law (n 61) art 23.

123 (2015) 33 Official Gazette of the Republic of Kosova (Kosovo).

124 (2013) 35 Official Gazette of the Republic of Kosova (Kosovo). 


\begin{tabular}{|c|c|c|c|c|c|}
\hline & & & $\begin{array}{l}\text { Acquisition of the } \\
\text { Citizenship by the } \\
\text { Stateless Person } \\
\text { and the Person with } \\
\text { Refugee Status } 125\end{array}$ & & \\
\hline Turkey & $\begin{array}{l}\text { Law No } 6458 \text { 'Law } \\
\text { on Foreigners and } \\
\text { International } \\
\text { Protection' }\end{array}$ & 2013 & $\begin{array}{l}\text { Implementing } \\
\text { Regulation on the } \\
\text { Law on Foreigners } \\
\text { and International } \\
\text { Protection }\end{array}$ & 2016 & Yes $^{126}$ \\
\hline Bulgaria & $\begin{array}{l}\text { Law on Foreigners } \\
\text { in the Republic of } \\
\text { Bulgaria }\end{array}$ & $\begin{array}{l}1998 \\
\text { amdt in } \\
2016, \\
2019\end{array}$ & $\begin{array}{l}\text { Regulations for the } \\
\text { Implementation of } \\
\text { the Law on } \\
\text { Foreigners in the } \\
\text { Republic of } \\
\text { Bulgaria } 127\end{array}$ & 2017 & No \\
\hline Montenegro & $\begin{array}{l}\text { Law 01-205/2 'Law } \\
\text { of Foreigners' }\end{array}$ & 2018 & $\begin{array}{l}\text { Rulebook on the } \\
\text { Procedure Initiated } \\
\text { upon Request for } \\
\text { Statelessness } \\
\text { Determination } 128 \\
\end{array}$ & 2018 & No \\
\hline Ukraine & $\begin{array}{l}\text { 1.Law on Ukrainian } \\
\text { Citizenship } \\
\text { 2. Law of Ukraine } \\
\text { on the Legal Status } \\
\text { of Foreigners and } \\
\text { Stateless Persons }\end{array}$ & $\begin{array}{l}1994 \\
\text { amdt in } \\
2011 \\
2020\end{array}$ & $\begin{array}{l}\text { Law of Ukraine on } \\
\text { the Legal Status of } \\
\text { Foreigners and } \\
\text { Stateless } \\
\text { Persons } 129\end{array}$ & 2020 & Yes $^{130}$ \\
\hline
\end{tabular}

C Asia

\begin{tabular}{|c|l|l|l|l|l|}
\hline Country & $\begin{array}{l}\text { Organic Law that } \\
\text { Makes Reference } \\
\text { to Statelessness }\end{array}$ & Year & $\begin{array}{c}\text { SDP: Law/ } \\
\text { Executive Branch } \\
\text { Decree, Resolution } \\
\text { or Application } \\
\text { Rules }\end{array}$ & Year & $\begin{array}{c}\text { SDP } \\
\text { Express } \\
\text { Reference } \\
\text { to Civil } \\
\text { Registry }\end{array}$ \\
\hline Philippines & $\begin{array}{l}\text { Commonwealth Act } \\
\text { No 613 'The } \\
\text { Philippine }\end{array}$ & 1940 & $\begin{array}{l}\text { Department } \\
\text { Circular No 058 } \\
\text { Establishing the }\end{array}$ & 2012 & No \\
\hline
\end{tabular}

125 (Kosovo). These instructions superseded and replaced the Administrative Instruction No 05/2015 for the Procedure and Criteria of Determining the Status of the Stateless Person, the Manner of Acquisition of the Citizenship by the Stateless Person and the Person with Refugee Status (2015) (Kosovo).

126 Turkish Implementing Regulation (n 91) art 49(3).

127 (2000) Prom SG 43 (Bulgaria). Adopted in 2011 by the Council of Ministers, Executive Branch. The first time SDPs were introduced in Bulgaria was through the amendment of these rules in 2017: Council of Ministers Decree No 122 of 23 June 2017 to Amend and Supplement the Regulations for Application of the Foreigners in the Republic of Bulgaria Act, Prom SG 51, [63](a). The latest modification of these rules was in 2019: Council of Ministers Decree No 88 of 17 April 2019 to Amend and Supplement Regulations for Application of the Foreigners in the Republic of Bulgaria Act, Prom SG No 34.

128 (2018) 72 Official Gazette of Montenegro (Montenegro).

129 As amended by Ukraine 2020 Statelessness Amendment (n 93). The SDP was introduced with the modification of the law in 2020 .

130 ibid art $6^{1}(2), 6^{1}(3)$. 


\begin{tabular}{|l|l|l|l|l|}
\hline $\begin{array}{l}\text { Immigration Act of } \\
1940\end{array}$ & $\begin{array}{l}\text { Refugees and } \\
\text { Stateless Status } \\
\text { Determination } \\
\text { Procedure, }\end{array}$ & & \\
& & & \\
\hline
\end{tabular}

D Africa

\begin{tabular}{|c|c|c|c|c|c|}
\hline Country & $\begin{array}{c}\text { Organic Law that } \\
\text { Makes Reference } \\
\text { to Statelessness }\end{array}$ & Year & $\begin{array}{c}\text { SDP: Law/ } \\
\text { Executive Branch } \\
\text { Decree, Resolution } \\
\text { or Application } \\
\text { Rules } \\
\end{array}$ & Year & $\begin{array}{c}\text { SDP } \\
\text { Express } \\
\text { Reference } \\
\text { to Civil } \\
\text { Registry } \\
\end{array}$ \\
\hline Côte d'Ivoire & - & - & $\begin{array}{l}\text { Interministerial } \\
\text { Order No } \\
837 / / M A E / M J D H \\
\text { of } 2 \text { September } \\
2020 \text { on the } \\
\text { Creation, } \\
\text { Organisation and } \\
\text { Functioning of the } \\
\text { National } \\
\text { Commission for the } \\
\text { Appeal of Stateless } \\
\text { Status } 131\end{array}$ & 2020 & No \\
\hline
\end{tabular}

131 Arrête Interministériel No 837//MAE/MJDH du 02 septembre 2020 portant création, organisation et fonctionnement de la Commission nationale de recours au statut d'apatride [Interministerial Order No 837//MAE/MJDH of 2 September 2020 on the Creation, Organisation and Functioning of the National Commission for the Appeal of Stateless Status] (Côte d'Ivoire). 